Review

\title{
Challenges in the PFAS Remediation of Soil and Landfill Leachate: A Review
}

Igor Travar ${ }^{1,}{ }^{*}$, Jean Noel Uwayezu ${ }^{2}$, Jurate Kumpiene ${ }^{2}$, Leo W.Y. Yeung ${ }^{3, *}$

1. Ragn Sells Treatment \& Detox AB, Box 952, 19129 Sollentuna, Sweden; E-Mail: igor.travar@ragnsells.com

2. Luleå University of Technology, Geosciences and Environmental Engineering, 97187 Luleå, Sweden; E-Mails: jean.noel.uwayezu@Itu.se; Jurate.Kumpiene@ltu.se

3. Örebro University, School of Science and Technology, SE-701 82 Örebro, Sweden; E-Mail: Leo.Yeung@oru.se

* Correspondence: Igor Travar and Leo W.Y. Yeung; E-Mails: igor.travar@ragnsells.com; Leo.Yeung@oru.se

Academic Editor: Zed Rengel

Special Issue: $\underline{\text { Remediation of PFAS (Per- and Polyfluoroalkyl Substances) Contamination }}$

Adv Environ Eng Res

2021, volume 2, issue 2

doi:10.21926/aeer.2102006
Received: December 15, 2020

Accepted: March 19, 2021

Published: April 19, 2021

\begin{abstract}
The use of per-and poly-fluoroalkyl substances (PFAS) has resulted in the contamination of different environmental matrices. In EU countries, the sites contaminated with PFAS are usually remediated by excavating the soil and disposing of it in a landfill, as no in-situ or onsite techniques capable of treating large quantities of soil cost-effectively have been developed. Landfilling of PFAS-contaminated soil is one of the sources of PFAS in landfill leachate. In this paper, the physical and chemical treatment methods to remove PFAS from soils and landfill leachates are described. Among the challenges that may limit the remediation of contaminated sites, we highlight the lack of strict regulation of PFAS in soils, the cost, the ineffectiveness of some methods for the remediation of certain PFAS compounds, and the limitation of the environmental matrices.
\end{abstract}

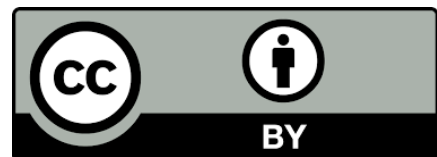

(C) 2021 by the author. This is an open access article distributed under the conditions of the Creative Commons by Attribution License, which permits unrestricted use, distribution, and reproduction in any medium or format, provided the original work is correctly cited. 


\section{Keywords}

Contaminated soil; landfill; leachate; treatment techniques; sorption; stabilization

\section{Introduction}

Per-and poly-fluoroalkyl substances (PFAS) have been widely used for more than 50 years as surfactants, coatings, water repellents for leather and textiles, impregnating agents, as well, in metal plating and aqueous film-forming foams (AFFFs) [1-3]. Today, more than 4,730 compounds related to PFAS are registered, and some of them are very mobile in the environment $[1,4]$. These substances have been detected in surface water [5-7], sediments downstream of the production facilities [8,9], groundwater [10,11], soil [12-16], wastewater treatment plant (WWTP) effluents $[17,18]$, and sewage sludge $[19,20]$. PFAS contamination in aquatic environments has been linked to major production sources [21, 22]. Additionally, effluents from WWTPs are another major source from which PFAS are introduced into the aquatic environment [22].

In general, PFAS are fluorinated aliphatic compounds with strong carbon and fluorine (C-F) bonds. The hydrogen atoms on all the carbon atoms have been replaced with fluorine in the perfluoroalkyl compounds, whereas hydrogens on some but not all carbon atoms are replaced with fluorine in the polyfluoroalkyl compounds (which also contain a perfluoroalkyl moiety, $C_{n} F_{2 n+1}$ ). Perfluoroalkyl sulfonic acids (PFSAs, $\mathrm{C}_{n} \mathrm{~F}_{2 n+1} \mathrm{SO}_{3} \mathrm{H}$ ), with 4-10 fully fluorinated carbon chains, and perfluoroalkyl carboxylic acids (PFCAs, $\mathrm{C}_{n} \mathrm{~F}_{2 n+1} \mathrm{COOH}$ ), typically with 3-15 fully fluorinated carbon chains, are the most commonly reported subgroups of PFAS [23]. Long-chain PFAS with $\geq 8$ carbon atoms are referred to as PFCAs, and those with $\geq 6$ carbon atoms are referred to as PFSAs [24]. These longchain compounds are characterized as non-biodegradable, highly persistent, potentially toxic, and bio-accumulative (in blood, liver, and kidneys) [25]. For these reasons, together with their widespread occurrence, PFAS have been highlighted as environmental and health hazards in recent years. Two compounds, in particular, perfluorooctanoic acid (PFOA, $\mathrm{C}_{7} \mathrm{~F}_{15} \mathrm{COOH}$ ) and perfluorooctane sulfonic acid (PFOS, $\mathrm{C}_{8} \mathrm{~F}_{17} \mathrm{SO}_{3} \mathrm{H}$ ), have been identified as the most abundant and widespread species in soil and aquatic environments [7, 11].

Excavation and landfilling are two conventional methods for the proper management of contaminated soils, although these are becoming less popular nowadays due to their high cost. Landfilled soils and other waste materials (e.g., carpets, textiles, paper, and packaging) containing PFAS may release these compounds in the leachate $[1,26,27]$, which can then migrate to the surrounding aquatic sources, particularly groundwater, due to the lack of barriers at old landfill sites or due to damage to the bottom liners [28]. Traditional facilities for leachate treatment at the landfills in Sweden (and worldwide) are inadequate in removing PFAS [1, 3, 29].

This review aims to evaluate the available techniques for PFAS treatment in soils before landfilling and the potential release of PFAS through landfill leachate, as well as to discuss the possible challenges of implementing these techniques for the remediation of contaminated sites. We have reviewed the current legal concentrations of PFAS in landfill soil and suggest revising the legislation on the landfilling of PFAS-containing materials. The reported concentrations of PFAS in the soil in contaminated areas were compared to assess the differences among contaminated sites and discuss the need for soil treatment. The chemical stability of the treated soil in landfills is also 
discussed and some knowledge gaps are identified. The concentrations of PFAS in landfill leachates in both new and old landfills are compiled to identify the differences among landfills globally and their environmental impacts.

\section{PFAS Regulations}

In 2004, the EU introduced Directive 850/2004 on Persistent Organic Pollutants (POPs), which restricted the marketing and use of PFOS [30]. The Directive applies to the substances and preparations of POPs with concentrations equal to or higher than $0.005 \%$ by mass (Table 1 ). A summary of the applicable regulations for PFAS in soil, waste, and groundwater is provided in Table 1. The Stockholm Convention includes PFOS and PFOA in the list of POPs, and these substances are restricted under the EU POP regulations [31]. PFHxS, which is currently being assessed under REACH for potential restriction, is also considered a candidate to be listed under the POPs by the Stockholm Convention [32]. No official guideline values have been published for the PFAS concentrations in soil that could pose a potential risk to human health or the environment, either at the EU level or the national level by the member states. The Swedish Geotechnical Institute (SGI) and the Swedish EPA have established preliminary guideline values for highly fluorinated substances in soil and groundwater, which recommend the maximum values of $0.003 \mathrm{mg} / \mathrm{kg}$ of PFOS in the soil for sensitive land use (e.g., residential land), $0.02 \mathrm{mg} / \mathrm{kg}$ of PFOS for less-sensitive land use (e.g., industrial land), and $0.045 \mu \mathrm{g} / \mathrm{L}$ of PFOS [33] in groundwater. In the US [34], different states have established different soil screening levels for groundwater protection which range from 0.00022 to $0.05 \mathrm{mg} / \mathrm{kg}$ of PFOS and 0.0015 to $19 \mathrm{mg} / \mathrm{kg}$ of PFOA, while the human health soil screening levels range from 0.5 to $6 \mathrm{mg} / \mathrm{kg}$ of PFOS and 0.33 to $16 \mathrm{mg} / \mathrm{kg}$ of PFOA (Table 1). In Canada, Health Canada has issued a direct contact residential soil screening value of $0.70 \mathrm{mg} / \mathrm{kg}$ for PFOA [35], and the Canadian Council of Ministers of the Environment has drafted guidelines for the protection of groundwater used for watering livestock and irrigation with the recommended PFOS limits of 12 $\mathrm{mg} / \mathrm{kg}$ (coarse soil) and $9 \mathrm{mg} / \mathrm{kg}$ (fine soil) [36]. Additionally, the Canadian Federal Soil Quality Guidelines (FSQGs) have prescribed the maximum concentrations of $0.01 \mathrm{mg} / \mathrm{kg}$ of PFOS in agricultural, residential, or parkland soil, $0.14 \mathrm{mg} / \mathrm{kg}$ of PFOS in coarse soil, and $0.21 \mathrm{mg} / \mathrm{kg}$ of PFOS in fine soil at the industrial sites [37]. In Australia, several guidelines for human health soil screening criteria have been issued: 1) residential areas with garden/accessible soil: $0.009 \mathrm{mg} / \mathrm{kg}$ of PFOS and $0.1 \mathrm{mg} / \mathrm{kg}$ of PFOA; 2) residential areas with minimal opportunities for soil access: $2 \mathrm{mg} / \mathrm{kg}$ of PFOS and $20 \mathrm{mg} / \mathrm{kg}$ of PFOA; 3) public open spaces: $1 \mathrm{mg} / \mathrm{kg}$ of PFOS and $10 \mathrm{mg} / \mathrm{kg}$ of PFOA; and 4) industrial/commercial areas: $20 \mathrm{mg} / \mathrm{kg}$ of PFOS and $50 \mathrm{mg} / \mathrm{kg}$ of PFOA, which represent the values applied to PFOS as well as to the summed concentrations of PFHXS and PFOS [38]. Although several reference values are available for soil, further assessment, such as a leachability test, should be performed to evaluate the potential risk of PFAS leaching from the soil to the surrounding environment. Waste classification in the EU is regulated by the Waste Framework Directive 2008/98/EC (which categorizes waste into inert, non-hazardous, and hazardous groups) [39] and the list of waste substances in Decision 2000/532/EC [40]. The EU Regulation 850/2004 (Appendix 7) for the waste management of POPs stipulates that the waste containing more than $50 \mathrm{mg} / \mathrm{kg}$ of PFOS should be destroyed or converted irreversibly, although it does not specify where this waste should be disposed of [41]. This may cause extremely high concentrations of PFOS in the landfills, which are the sources of PFAS contamination in landfill leachate. Moreover, inappropriate landfilling 
(e.g., highly contaminated waste disposed at landfills for inert or non-hazardous waste) may pose a high risk of PFAS leakage into the environment. Legal concentrations of PFAS in waste need to be revised, and maximum limits of PFAS concentrations in treated leachate should be established to minimize the risk of contamination of the recipients.

Table 1 Summary of the available regulations for PFAS in soil, waste, and groundwater.

\begin{tabular}{|c|c|c|c|c|}
\hline Country & Regulation & Subject & Limit values & Reference \\
\hline EU & $\begin{array}{l}\text { Directive } 850 / 2004 \\
\text { on Persistent Organic } \\
\text { Pollutants (POPs) }\end{array}$ & $\begin{array}{l}\text { prohibiting, } \\
\text { phasing out or } \\
\text { restricting the } \\
\text { production, placing } \\
\text { on the market and } \\
\text { use of } \\
\text { substances subject } \\
\text { to the Stockholm } \\
\text { Convention on POPs }\end{array}$ & $\begin{array}{l}\text { Waste containing more } \\
\text { than } 50 \mathrm{mgPFOS} / \mathrm{kg} \text { TS } \\
\text { should be destructed }\end{array}$ & {$[30,41]$} \\
\hline Sweden & $\begin{array}{l}\text { Regulation under } \\
\text { construction }\end{array}$ & $\begin{array}{l}\text { Suggested values of } \\
\text { PFOS in soil and } \\
\text { ground water }\end{array}$ & $\begin{array}{l}\text { PFOS }<3 \mu \mathrm{g} / \mathrm{kg} \text { in soil for } \\
\text { sensitive land use } \\
\text { PFOS }<20 \mu \mathrm{g} / \mathrm{kg} \text { in soil for } \\
\text { less sensitive land use } \\
\text { PFOS }<0.045 \mu \mathrm{g} / \mathrm{L} \text { in } \\
\text { groundwater }\end{array}$ & [33] \\
\hline \multirow[t]{2}{*}{ USA } & $\begin{array}{l}\text { Regulations, } \\
\text { Guidance, and } \\
\text { Advisories for Per- } \\
\text { and Polyfluoroalkyl } \\
\text { Substances }\end{array}$ & $\begin{array}{l}\text { levels of PFOS and } \\
\text { PFOA in soil for } \\
\text { ground water } \\
\text { protection }\end{array}$ & $\begin{array}{l}\text { PFOS in soil from } 0.22 \text { to } \\
50 \mu \mathrm{g} / \mathrm{kg} \\
\text { PFOA in soil from } 1.5 \text { to } \\
19000 \mu \mathrm{g} / \mathrm{kg}\end{array}$ & [34] \\
\hline & & $\begin{array}{l}\text { Levels of PFOS and } \\
\text { PFOA in soil for } \\
\text { human health } \\
\text { protection }\end{array}$ & $\begin{array}{l}\text { PFOS in soil from } 0.5 \text { to } 6 \\
\mathrm{mg} / \mathrm{kg} \\
\text { PFOA in soil from } 0.33 \text { to } \\
16 \mathrm{mg} / \mathrm{kg} \text { PFOA }\end{array}$ & [34] \\
\hline Canada & $\begin{array}{l}\text { Updates to Health } \\
\text { Canada Soil } \\
\text { Screening Values for } \\
\text { PFAS \& Canadian } \\
\text { Environmental } \\
\text { Protection Act }\end{array}$ & $\begin{array}{l}\text { Concentrations of } \\
\text { PFOA in residential } \\
\text { and parkland soil, } \\
\text { agricultural soil and } \\
\text { soil at industrial sites }\end{array}$ & $\begin{array}{l}\text { Residential, parkland and } \\
\text { agricultural soil } \\
\text { PFOA }<0.70 \mathrm{mg} / \mathrm{kg} \text { and } \\
\text { PFOS }<0.01 \mathrm{mg} / \mathrm{kg} \\
\text { Industrial sites } \\
\text { PFOS }<0.14 \quad \mathrm{mg} / \mathrm{kg} \text { in } \\
\text { coarse soil and } \\
\text { PFOS }<0.21 \mathrm{mg} / \mathrm{kg} \text { in fine } \\
\text { soil }\end{array}$ & {$[35,37]$} \\
\hline
\end{tabular}




$$
\begin{aligned}
& \text { Concentrations of } \\
& \text { PFOS in water used } \\
& \text { for livestock } \\
& \text { watering and } \\
& \text { irrigation to protect } \\
& \text { groundwater }
\end{aligned}
$$

\begin{tabular}{|c|c|}
\hline \multirow{4}{*}{ Australia } & Commonwealth \\
\hline & Environmental \\
\hline & Management \\
\hline & $\begin{array}{l}\text { Guidance on PFOS } \\
\text { and PFOA }\end{array}$ \\
\hline
\end{tabular}

Residential soil: PFOS $=9$

$\mu \mathrm{g} / \mathrm{kg} \& \mathrm{PFOA}=100$ $\mu \mathrm{g} / \mathrm{kg}$;

Residential with minimal opportunities for soil access: $P F O S=2 \mathrm{mg} / \mathrm{kg} \&$ $P F O A=20 \mathrm{mg} / \mathrm{kg}$

Public open space: PFOS =

$1 \mathrm{mg} / \mathrm{kg} \& \mathrm{PFOA}=10$

$\mathrm{mg} / \mathrm{kg}$

Industrial/Commercial:

PFOS $=20 \mathrm{mg} / \mathrm{kg} \& \mathrm{PFOA}$

$=50 \mathrm{mg} / \mathrm{kg}$

\section{PFAS in Contaminated Soil}

Fire-fighting training areas and manufacturing plants are the largest sources of PFAS in soil. PFOS are the most intensively studied PFAS contaminants in the soil at fire-fighting training facilities [9, $16,17]$. However, the contribution of PFOS to total PFAS at the sites may be over-estimated as there would be several other PFAS that were not previously included in the analysis. These overlooked PFAS might be the novel ones, such as chlorinated, dechlorinated, and ketone PFSA, perfluoroalkane sulphonamides (FASAs), 6:2 fluorotelomer sulphonamidoalkyl betaine, 6:2 and 8:2 fluorotelomer sulfonates, or short-chain perfluorocarboxylic acids [6, 42]. In a study published in 2014 on the chemical analysis of selected fire-fighting foams from the Swedish market, PFHxA and 6:2 FTSA were found in considerably high concentrations in the foams, with some 6:2 fluorotelomer-based products also identified in most of the foam samples [43]. The reported ranges of PFOS concentrations in soil were 6.4-2400 $\mu \mathrm{g} / \mathrm{kg}$ at Oslo airport, Norway [16], 21-120 $\mu \mathrm{g} / \mathrm{kg}$ at Kristianstad, Bergen, and Hastad airports in Norway [16], 2.2-8520 $\mu \mathrm{g} / \mathrm{kg}$ at Tullinge, Sweden [9], and 21-2400 $\mu \mathrm{g} / \mathrm{kg}$ at Ellsworth Air Force Base, USA [17]. Additionally, an extremely high concentration (36000 $\mu \mathrm{g} / \mathrm{kg}$ ) of PFOS was reportedly found near a burning pit at a former firefighter training area at the Ellsworth Air Force Base [44]. The PFAS concentrations and the number of contaminated sites across the world suggest that soil is a major environmental reservoir of PFAS [15].

Hale et al. [16] and Filipovic et al. [9] found the highest concentrations of PFOS at 1-2 m below the soil, suggesting that PFOS can gradually migrate down the layers of soil with the rainwater. This migration of PFAS through the soil is complex and depends on several factors, such as the properties of PFAS, the soil properties, and the climatic conditions. Depth-profile data and mathematical modeling have demonstrated that the PFAS in the soil can be retained in the vadose zone for 
decades, mostly due to the adsorption of PFAS at the air-water interface as well as on soil grain surfaces $[14,15]$.

The transport of PFAS through the soil may result in the contamination of groundwater, surface water, and drinking water wells, along with the contamination of biota. Filipovic et al. [9] reported large differences in the concentrations of PFOS between the surface water (1.1-79 ng/L) and groundwater (1-51000 $\mathrm{ng} / \mathrm{L}$ ) close to an old air-force base at Tullinge near Stockholm [8]. The contamination of groundwater may occur over decades or centuries since contaminated soil acts as a reservoir of PFAS and the transport of PFAS through soil is quite slow [14, 15]. Thus, it is necessary to remediate the contaminated areas to prevent contamination of watercourses. One of the most common techniques for the remediation of the hotspots contaminated with PFAS is "digging and dumping". Although this strategy entails costly landfilling, sometimes without proper handling and disposal facilities, its application has been continued due to the deficiencies in and the uncertainties of in-situ (on-site) techniques for treating PFAS-containing soils. Disposal of contaminated soil in a landfill from a site without treatment is merely a transfer of the problem of one site to another. Thus, PFAS-contaminated soils need to be treated before disposal to minimize further environmental problems associated with the contamination of non-contaminated areas and drinking water sources.

\section{Influence of the Landfill Environment on the Release of PFAS from Contaminated Soil}

The solubility of PFAS in the contaminated soil in a landfill should be kept low to avoid contamination from leachates. However, many factors in a landfill may influence the release of PFAS from the soil. Infiltration of the precipitation into the system, the type of waste, the degradation of disposed waste, and the operating conditions (e.g., compaction of wastes, gas collection system, leachate recirculation) [45] are the factors that can affect the $\mathrm{pH}$, redox conditions, temperatures, and stability of PFAS in landfills [26, 46-49]. The infiltration of precipitation, moisture content, leachate production, and release of PFAS from the soil in landfills are positively correlated $[26,27]$. Thus, the installation of a landfill cover reduces the production of leachate and the release of PFAS. Moreover, the reduction of infiltration reduces the microbial activity (and gas production) in the landfills, which may, in turn, reduce the release of PFAS [50, 51].

Encapsulation of PFAS-contaminated soil (e.g., with a geomembrane or clay minerals) after disposal in a landfill (during active landfilling) may prevent or reduce the contact between PFAS and the leachate, and the subsequent release from the soil. However, this technique may not have longterm (several decades to centuries) efficacy due to the potential for damage to the geomembrane and percolation of the leachate through the layer of clay [52].

Degradation of organic waste occurs in several landfilling phases, including the aerobic, acidogenic, and methanogenic phases, in which the leachate has characteristic $\mathrm{pH}$ values and composition (both organic and inorganic) [53]. Alkaline soils may promote the leaching of PFAS from the soil since the sorption of PFAS to the soil has been shown to decrease with an increase in the $\mathrm{pH}$ of the leachate. This is due to a reduction in the protonation of the adsorbent surfaces and the associated reduction in the frequencies of positively-charged sites on the sorbent [54-56]. Thus, landfilling of PFAS-contaminated soil together with alkaline materials should be avoided.

The anaerobic microbial biotransformation of precursors (e.g., polyfluoroalkyl phosphate esters) may generate fluorotelomer alcohols, followed by perfluorinated/polyfluorinated acids but is 
probably not a major source of the PFCAs detected in anaerobic environmental matrices under methanogenic conditions [57]. This observation suggests that PFAS-contaminated soil in landfill cells, together with other biodegradable organic wastes, may reduce the degradation of PFAS precursors. However, a shift in conditions from reduction to oxidation can be expected as landfills age. Oxidation of precursors in a landfill may generate more contaminated leachate. For example, Houtz et al. [17] estimated that the oxidation of precursors accounted for $23 \%$ and $28 \%$ of total PFAS on average in groundwater and soil samples, respectively. Therefore, it is important to maintain a low redox potential in a landfill to reduce the mobility of PFAS.

Landfill leachate has a complex chemical composition, and the effects of its composition on the leaching of PFAS from the waste into the landfills are not well documented. For example, anions in leachates (e.g., $\mathrm{Cl}^{-}, \mathrm{SO}_{4}{ }^{2}, \mathrm{Cr}_{2} \mathrm{O}_{7}{ }^{2-}$ ) and dissolved organic content (DOC) may increase the mobility of negatively-charged PFAS as they compete for the same (positively charged) adsorption sites $[47,58]$. This suggests that variation in leachate quality likely contributes to the variability and patterns of PFAS concentrations in leachates [28]. Operating temperatures in a landfill may also affect the mobility of PFAS. For example, Kim et al. reported enhanced release of PFAS (especially PFHxA and PFHpA) with an increase in the contact time and temperature [59], whereas Jia et al. found that sorption of PFOS on humic acids (the main components of organic matter in sediments) doubled when the temperature increased from $5^{\circ} \mathrm{C}$ to $35^{\circ} \mathrm{C}$ [49]. Thus, due to inconsistencies in the findings, more research is needed to clarify the effects of temperature on the release of PFAS from contaminated soils.

Some PFAS that leach from the soil are likely to be re-adsorbed as the leachate percolates through a landfill, for example, on carbonaceous surfaces or humic acids in the waste [49]. Such readsorption has not been addressed in any study, although analogous sorption of PFAS on the sediments near WWTPs (particularly long-chain PFAS) has been reported $[21,60]$. Thus, waste in a landfill could potentially serve as a filter for the PFAS leached from contaminated soils, although further research is required to test this hypothesis.

\section{PFAS in Landfill Leachate}

Around 140-188 million tons of total annual municipal solid waste is disposed of in landfills in the USA and Europe $[61,62]$. In Europe and Australia, waste containing $50 \mathrm{mg} / \mathrm{kg}$ of PFOS can be disposed of in landfills without any pre-treatment $[41,63]$. In the USA, the calculated annual PFAS disposal rate is $1,250 \mathrm{~kg} /$ year for municipal solid waste and $470-590 \mathrm{~kg} /$ year for biosolids [64]. The waste containing PFAS spreads in landfill leachates. A total of 17 studies have reported the concentrations of PFAS in landfill leachates, including seven conducted in North America [27, 29,45, 51, 65-67], seven in Europe [1, 64, 68-72], two in China [3, 73], and one in Australia [74]. The concentrations of PFAS in the leachates from active landfills vary by several orders of magnitude. For example, total reported PFAS (LPFAS) concentrations in the leachates from Canadian and Chinese landfills ranged from 27 to $21,300 \mathrm{ng} / \mathrm{L}$ and 7,280 to $290,000 \mathrm{ng} / \mathrm{L}$, respectively $[3,29,67$, 75]. This variation is less pronounced in closed landfills than active landfills, as was reported in a study on Australian landfills (2016). Lang et al. [27] found that the concentrations of only six (PFNA, 8:2 FTCA, 5:3 FTCA, PFBS, MeFBSAA, and MeFOSAA) of the 70 PFAS analyzed were significantly higher in the younger US landfills than in the older ones. This could be due to reductions in the concentrations of these species with time or changes in the types of PFAS used in products in recent 
years (e.g., a shift to the use of PFBS-based and fluorotelomer-based products instead of PFOS and PFOA). The similarity in the concentrations of almost all the analyzed PFAS in the leachates from old and young landfills indicates that PFAS may be released for many years after the disposal of the soil.

Concentrations of PFAS in landfill leachates and volumes of accumulated leachates must be known when evaluating the hazards posed by landfills, particularly the risk of PFAS contamination to the aquatic environment. For example, Busch et al. [1] estimated that discharges of $\sum$ PFAS from 22 landfills in Germany ranged between 0.08 and $956 \mathrm{mg} /$ day (mean: $135 \mathrm{mg} /$ day), and the total discharges from all landfill sites in Germany (ca. 1,700) amounted to approximately $240 \mathrm{~g}$ of total PFAS/day, on average. Fuertes et al. [71] estimated a 1,209 g/year mass flow of PPFAS from four studied landfill sites serving a population of about 1.8 million people in northern Spain. In the USA, landfills released 563-638 kg of LPFAS to WWTPs via leachates in 2013 [27]. The actual amount of PFAS in landfill leachate in the USA could be higher as the cited authors' analyses did not include total oxidizable precursor or total fluorine assays. Furthermore, Yan et al. [3] estimated that approximately $3,110 \mathrm{~kg}$ of PFAS is released in landfill leachates in China annually. Thus, landfill leachates can be a significant source of PFAS contamination in the environment. PFAS should, thus, be removed from leachates before discharging to recipients, such as WWTPs, rivers, or lakes [65].

\section{Treatment of PFAS-Contaminated Soil before Landfilling}

\subsection{Removal of PFAS from Contaminated Soil through Washing}

Soil washing involves the separation of PFAS-contaminated particles from the bulk of the soil, followed by the extraction or desorption of PFAS from those particles (Figure 1). Mechanical separation is suitable for coarse-grained soils (e.g., soils dominated by stones and gravel), but it is not economically viable for fine-grained soils (dominated by fine sand, silt, and clay) [16]. Chemical extraction of PFAS should be performed on fine-grained soil particles under saturated conditions to enhance the treatment and minimize the adsorption of PFAS in unsaturated soils (see Section 3). Extraction agents, such as methanol/sodium hydroxide ( $\mathrm{MeOH} / \mathrm{NaOH})$, methanol/ammonium hydroxide $\left(\mathrm{MeOH} / \mathrm{NH}_{4} \mathrm{OH}\right)$ and acetonitrile $\left(\mathrm{CH}_{3} \mathrm{CN}\right)$, and water, have been used to extract PFAS from contaminated soils in the laboratory under saturated conditions [16, 42, 54]. Hale et al. [16] found that in the determination of the total concentration of PFOS in the soil, water extracted more PFOS compared to either methanol or acetonitrile, indicating that water could serve as an excellent extraction agent. However, extraction efficiency depends not only on the type of extraction agent but also on the soil properties (e.g., organic matter and clay content) [16, 60]. Removing PFAS by washing may be feasible for soils with low DOC (0.7-6 mg/L) and soils with low clay content (e.g., soils predominantly composed of sand) at an alkaline $\mathrm{pH}[16,60]$. In addition to the treated soil, this technique generates large amounts of contaminated process water that needs further treatment. Soil washing has been used to remove PFAS commercially in-situ ("flushing") but not for the treatment of soil before landfilling due to the high costs involved [54]. 


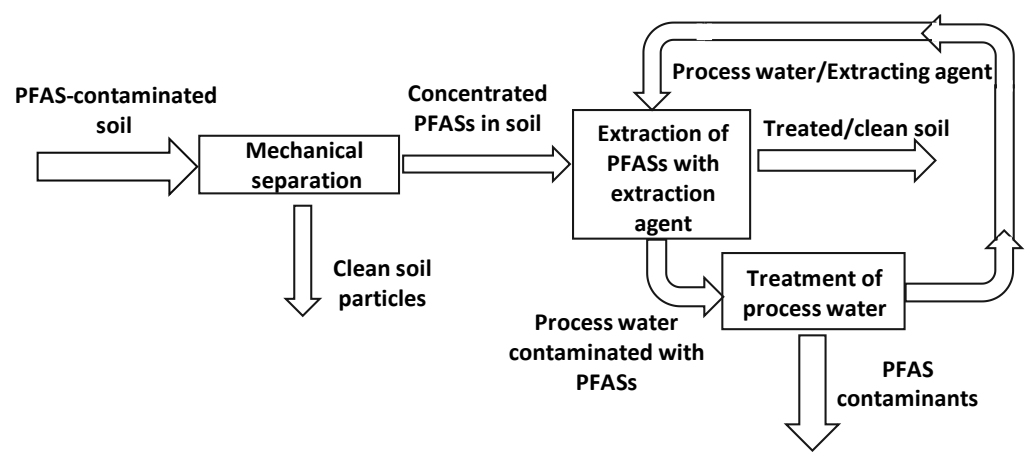

Figure $1 \mathrm{~A}$ combined treatment of PFAS-contaminated soil consisting of mechanical separation of the contaminated particles from the soil mass and the extraction of PFAS using an appropriate agent.

\subsection{Stabilization and Solidification of PFAS in Contaminated Soil}

Stabilization of PFAS in contaminated soil refers to the immobilization of PFAS by the addition of a substance that reduces mobility through leaching. Solidification of PFAS-contaminated soil involves the mixing of a cementitious binder and additives into the contaminated matrix to reduce hydraulic conductivity and PFAS exposure to leaching. Detailed knowledge of PFAS sorption behavior is essential for developing effective stabilization techniques to manage contaminated soils. The most important types of interactions involved in the sorption of PFAS to potential sorbents are electrostatic interactions, hydrophobic interactions, and ion exchange [56, 76, 77]. Electrostatic interactions between PFAS in solution and sorbents rely significantly on the $\mathrm{pH}[46-48,78]$. Anionic PFAS are adsorbed on the positively-charged surfaces of the sorbents $[47-49,79]$. When the $\mathrm{pH}$ of a PFAS-contaminated solution becomes more acidic than the adsorbent's $\mathrm{pHpzc}$ (pH at the point of zero charge), the number of positively-charged sites on the sorbent increases (by surface protonation), and the adsorption of these PFAS is enhanced [76]. Hydrophobic interaction between PFAS and sorbents is the strongest when the sorbents are uncharged $[60,76]$. Ion exchange is the dominant mechanism for the immobilization of anionic PFAS, especially for short-chain PFAS, when the anion-exchange resin is used [73]. The described sorption mechanisms of PFAS on sorbents are quite complex as the immobilization of PFAS in stabilized soil depends not only on the properties of the added sorbent but also on the soil characteristics (e.g., organic matter content) and leaching conditions (e.g., $\mathrm{pH}$, redox potential, and temperature). Both inorganic and organic substances have been tested as possible PFAS adsorbents under experimental conditions, mostly in soil-free conditions. The inorganic substances include sand, high iron sand, kaolinite, $\mathrm{Fe}_{2} \mathrm{O}_{3}$ (hematite), alumina, zeolite, hydrotalcite, montmorillonite, $\mathrm{FeO}(\mathrm{OH})$ (goethite), and modified commercial clay $[48,73,80,81]$. The organic substances include oil, black carbon, activated carbon (AC), biochar (BC), and ion-exchange resin [16, 82-85]. However, only four of the reviewed studies $[16,80,84,86]$ included tests evaluating the PFAS sorption efficiency in the presence of soil and only one published study described the solidification of PFAS-contaminated soil [86]. The stabilization efficiency of the substances should be verified in the presence of soil containing multiple contaminants collected from a field site. 


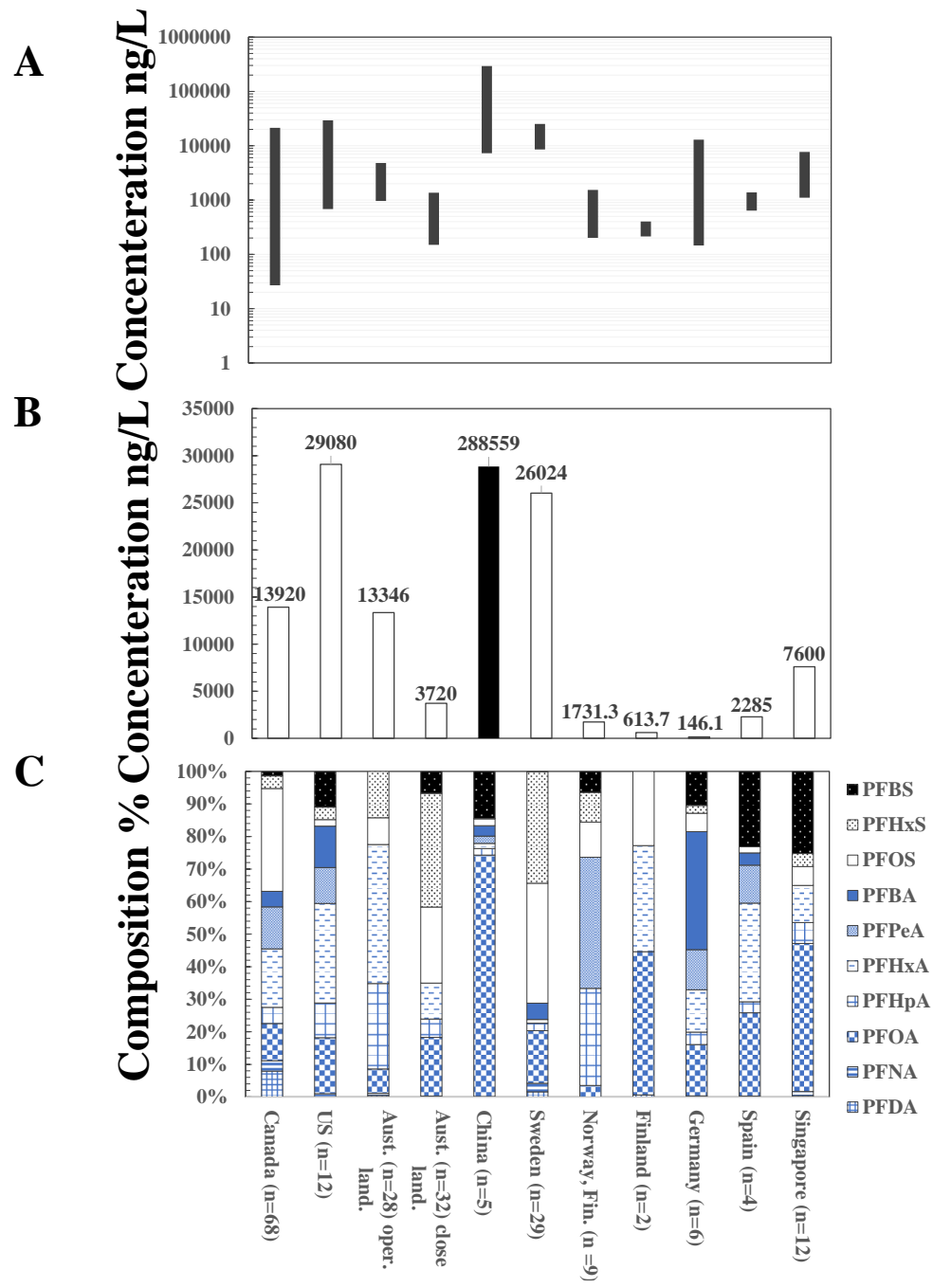

Figure 2 Graphs showing (A) Graphs showing minimum and maximum concentrations ( $\mathrm{ng} / \mathrm{L}$ ) of $\sum$ PFAS in raw leachate; (B) Graphs showing average concentrations (ng/L) of ¿PFAS in raw leachate. (The bar in black does not fit onin the y-axis.); and (C) Graphs showing the composition of PFAS (\%) in the raw leachate. Ref. From earlier studies: Canada [29, 67, 75], the USA [45, 51], Australia [74], China [3], Sweden [64, 72], Norway and Finland [68], Finland [70], Germany [1], Spain [71], and Singapore [87].

\subsubsection{Treatment of PFAS-Contaminated Soil Using Activated Carbon (AC) and Biochar (BC)}

Biochar is a type of charcoal produced mainly from biomass (e.g., mixed wood, coconut husks, or bamboo) through pyrolysis (thermal decomposition of organic matter in the absence of oxygen). Granulated AC (GAC) and powdered AC (PAC) are produced similarly (using biomass, coal, and peat), in combination with physical activation (using hot gases) or chemical activation (with acid or base, such as $\mathrm{H}_{3} \mathrm{PO}_{4}, \mathrm{KOH}$, and $\mathrm{NaOH}$ ), to increase the pore volume and surface area. Both $A C$ and $\mathrm{BC}$ treatment technologies have been used in the remediation of soil, groundwater, and drinking water contaminated with PFAS $[16,83,84,88]$. AC is more suitable for remediation as its pore structure provides considerably large specific surface areas, pore volumes, and sorption capacities for organic pollutants (Table 2). 
Table 2 Chemical composition, surface area (SA), pore volume (PV), soil-water distribution coefficient $\mathrm{K}_{\mathrm{d}}$ (in $\mathrm{L} / \mathrm{kg}$ ), and organic carbon normalized sediment-water distribution coefficient logKoc (estimated as $K_{d} / f_{o c}$ ) of soil, and the soil treated with powdered activated carbon (PAC), mixed wood biochar (MW $B C)$, paper mill waste biochar (PMW BC) $[8,16,76,84,89]$.

\begin{tabular}{|c|c|c|c|c|}
\hline & Soil/sediment & PAC & $\mathrm{MW} \mathrm{BC}$ & PMW BC \\
\hline $\mathrm{pH}$ & & $9.6[84]$ & $9.6[84]$ & $9.5[84]$ \\
\hline \multicolumn{5}{|c|}{ Chemical composition, $\%$} \\
\hline $\mathrm{C}$ & & $81[84]$ & $53[84]$ & $19[84]$ \\
\hline $\mathrm{H}$ & & $0.03[84]$ & $0.8[84]$ & $0.5[84]$ \\
\hline $\mathrm{N}$ & & $0.2[84]$ & $0.3[84]$ & $0.1[84]$ \\
\hline $\mathrm{O}$ & & $8.4[84]$ & $2.5[84]$ & $9.4[84]$ \\
\hline \multicolumn{5}{|c|}{ Physical properties } \\
\hline $\mathrm{SA}, \mathrm{m} 2 / \mathrm{g}$ & & $346-812[16,76,84]$ & $404-520[84]$ & $13.2-48[84]$ \\
\hline $\mathrm{PV}, \mathrm{cm} 3 / \mathrm{g}$ & & $0.27-0.6[84]$ & $0.14-0.19[84]$ & $0.01-0.09[84]$ \\
\hline \multicolumn{5}{|c|}{ Soil-water distribution coefficient logKd $(\mathrm{L} / \mathrm{kg})$} \\
\hline PFBA (C4) & $1.1-<2.3[84]$ & $3.01[84]$ & $1.1-<2.2[84]$ & $1-<2.2[84]$ \\
\hline PFHxS (C6) & $1.2-1.8[84]$ & $3.5[84]$ & $1.4-1.8[84]$ & $1.3-1.8[84]$ \\
\hline PFOS (C8) & $1.3-3.8[8,16,76,89]$ & $3.8-4.6[16,76,84]$ & $1.8-3.1[84]$ & $1.8-3[84]$ \\
\hline PFOA (C8) & $0.3-4[76,89]$ & $3.3-4[76,89]$ & $2.2-4[84]$ & $3-4[84]$ \\
\hline PFNA (C9) & $2.3-<2.6[84]$ & $>3[84]$ & $2.2-<2.8[84]$ & $2.1-<2.8[84]$ \\
\hline \multicolumn{5}{|c|}{ Organic carbon normalized sediment-water distribution coefficient logKOC (L/kg) } \\
\hline PFBA (C4) & $1.8-<4.8[84]$ & $4[84]$ & $2.4-4.8[84]$ & $2.3-4.8[84]$ \\
\hline PFHxS (C6) & $1.8-4[84]$ & $3.9-5.8[84]$ & $1.8-4[84]$ & $1.8-4[84]$ \\
\hline PFOS (C8) & $2.9-4.3[76,89]$ & 4.3-7.2 [76, 89] & $2.9-4.5[80]$ & $3.1-4.4[84]$ \\
\hline PFOA (C8) & $1.9-2.6[8,76,89]$ & 4.4-5.5 [76, 89] & $2-4.7[84]$ & $2.1-4.6[84]$ \\
\hline PFNA (C9) & $<2.8-<5.3[84]$ & $>4[84]$ & $<2.9-<5[84]$ & $<3.1-<5.5[84]$ \\
\hline
\end{tabular}

Hale et al. [16] observed that the addition of 3\% PAC (in a specific area of $726 \mathrm{~m}^{2} / \mathrm{g}$ ) to contaminated soil in batch leaching tests reduced the leaching of PFOS by $94 \%-99.9 \%$, from $6.4-54.5$ $\mu \mathrm{g} / \mathrm{kg}$ to $0.003-0.43 \mu \mathrm{g} / \mathrm{kg}$. Modeling of these results using a one-dimensional box model indicated that this would reduce the concentrations of PFOS in pore water from $19.5 \mu \mathrm{g} / \mathrm{L}$ to $0.4 \mu \mathrm{g} / \mathrm{L}$, just above the clean-up target of $0.3 \mu \mathrm{g} / \mathrm{L}$. The same model indicated that PFOS would be released slowly from the untreated soils, taking more than 100 years to decrease the pore water concentrations of PFOS below the arbitrary target. This suggests that PAC might serve as an effective sorbent to diminish releases from contaminated soil to the surrounding environment, although more information is needed to confirm its efficacy. For example, further investigation is needed to determine the suitability of the method for field application, PAC's durability in soil, and the subsequent release of immobilized PFAS (i.e., the long-term treatment efficiency), as well as, the material costs and the wider environmental impacts of the process.

Biochar could immobilize PFAS in solution in sorption experiments (as shown by the Freundlich sorption coefficients presented in Table 2 ) but could not immobilize PFAS in soils in batch leaching 
tests [84]. This is probably due to the blockage of biochar pores with dissolved compounds and particles (e.g., humic substances and oil) in the soil [84]. Moreover, other soil components (e.g., DOC and ions) can compete with PFAS for the sorption sites [47, 90, 91]. The effectiveness of BC in immobilizing PFAS may be higher in the soils with lower organic content (e.g., total organic carbon $(\mathrm{TOC})<3 \%$ in dry mass), indicating that for successful amendment, the amount of carbonaceous material added to the contaminated soil should exceed the initial carbon content of the soil [84, 92]. Thus, BC can be used for the sorption of PFAS in soils with low organic content.

The effectiveness of soil treatment with carbonaceous amendments (CAs), such as PAC and BC, depends not only on the CA but also on the chain-length of the PFAS. For example, the logarithm of the distribution coefficient $\left(\log K_{d}\right)$ of PFBA in the soil stabilized with PAC is about $3.01 \mathrm{~L} / \mathrm{kg}$, whereas, the log $K_{d}$ of PFOS in the same system varies between 3.8 and $4.8 \mathrm{~L} / \mathrm{kg}[13,28]$ (Table 3). These results show that PFAS with longer chains (e.g., PFOS and FOSA) bind more strongly to CA than those with shorter chains, indicating the importance of hydrophobic interactions in the sorption of PFAS (Higgins and Luthy, 2006). Moreover, PFAS with a sulfonate moiety have stronger adsorption than those with a carboxylate moiety (e.g., in the soil stabilized with PAC, the logK $K_{d}$ of PFOS reportedly varies between 3.8 and $4.6 \mathrm{~L} / \mathrm{kg}$, while the $\log \mathrm{K}_{d}$ of PFNA is about 3; see Table 2). This is probably due to the slightly higher hydrophobicity of the slightly larger sulfonate moiety and/or differences in the specific electrostatic interactions of these moieties [60, 84]. Moreover, short-chain PFAS and fluorotelomers (which have a partially fluorinated carbon chain) can be more easily desorbed from the sediments with a low fraction of organic carbon (e.g., $f_{o c}$ of $0.03 \%$ ) in the aqueous phase than the species with longer chains or fully-fluorinated carbon chains (e.g., PFOS and FOSA) [84]. For example, Ahrens et al. [8] and Kupryianchyk et al. [84] calculated the carbon-normalized distribution coefficients and $\log \left(\mathrm{K}_{\mathrm{d}} / \mathrm{f}_{\mathrm{oc}}\right)$ values of 2.9-4.3 L/kg for PFOS and 2.1-2.6 L/kg for PFOA. Thus, it is important to add enough CA to PFAS-soil to ensure the stability of immobilized substances. Normally, PFAS-contaminated soils are remediated with 2\%-4\% CA (about 30-60 t/ha, assuming mixing to a depth of ca. $10 \mathrm{~cm}$ and soil density of ca. $1.5 \mathrm{~kg} / \mathrm{m}^{3}$ ) in-situ [11]. Whether this amount of CA is sufficient to stabilize soils in landfills remains unknown as no relevant information was found in the reviewed papers.

Table 3 Comparison of $\angle$ PFAS in untreated and treated leachate with respective treatments [1, 87]. WAO-wet air oxidation, AC-activated carbon, CW-constructed wetlands.

\begin{tabular}{|c|c|c|c|c|c|}
\hline $\begin{array}{l}\text { Treatment } \\
\text { method }\end{array}$ & $\begin{array}{l}\sum \text { PFAS in } \\
\text { untreated leachate, } \mathrm{ng} / \mathrm{L}\end{array}$ & $\begin{array}{l}\sum \text { PFAS } \\
\text { treated } \\
\mathrm{ng} / \mathrm{L}\end{array}$ & $\begin{array}{r}\text { in } \\
\text { leachate, }\end{array}$ & Landfill status & Reference \\
\hline WAO & 1889 & 1993 & & inactive & [1] \\
\hline$A C$ & 31 & 9 & & inactive & [1] \\
\hline$A C$ & 12819 & 4079 & & inactive & [1] \\
\hline$A C$ & 8370 & 20 & & active & [1] \\
\hline $\mathrm{CW}$ & 814-4324 & $367-954$ & & active & [87] \\
\hline
\end{tabular}




\subsubsection{Treatment of PFAS-Contaminated Soil with Compost}

Hale et al. [16] found that treating contaminated soil with $3 \%$ compost (composed of peat and cow manure with a high content of nitrogen, phosphate, and potassium) reduced PFOS leaching by $29 \%-34 \%$, from $3.8 \pm 2.4$ to $2.54 \pm 1.5 \mu \mathrm{g} / \mathrm{L}$; the calculated distribution coefficient $\left(\mathrm{K}_{\mathrm{d}}\right)$ of PFOS between compost and soil was $8.8 \mathrm{~L} / \mathrm{kg}$. Sorption of PFAS on compost occurs probably through direct polar interactions, hydrophobic interactions, ion-exchange, and addition to more specific sites of moieties with an affinity for PFAS present in the organic matter [16, 79]. More information is, nonetheless, needed on the sorption of PFAS using compost, the influence of co-contaminants, the stability of immobilized PFAS, and the efficacy of the treatment.

\subsubsection{Treatment of PFAS-Contaminated Soil with Clay Minerals (Montmorillonite and Kaolinite)}

Soil rich in clay minerals, such as montmorillonite and kaolinite, can be used to stabilize PFAScontaminated soil. For example, Hale et al. [16] found that treating contaminated soil with $3 \%$ montmorillonite decreased the release of PFOS by $28 \%-40 \%$, from $3.8 \pm 2.4 \mu \mathrm{g} / \mathrm{L}$ to $2.7 \pm 1.8 \mu \mathrm{g} / \mathrm{L}$. The reported $\mathrm{K}_{\mathrm{d}}$ values for the sorption of PFOS to montmorillonite were in the range of $5-10 \mathrm{~L} / \mathrm{kg}$ $[16,93]$. Hydrophobic and electrostatic interactions are the main mechanisms involved in the adsorption of PFOS to montmorillonite and kaolinite. More specifically, PFOS may be immobilized via the formation of outer-sphere surface complexes and specific interactions of the sulfonate group of PFOS with the hydroxyl groups on the surfaces of clay minerals [94]. However, dissolved humic substances in soil were shown to hinder the adsorption of PFOS on clay minerals via electrostatic repulsion and occupation of adsorption sites [93]. Thus, treatment with clay minerals can be effective for PFAS-contaminated soils with low organic matter, such as soils predominantly composed of stones and sand. Moreover, the addition of clay particles to such soil probably reduces its hydraulic conductivity, and hence, the contact between the contaminated soil and infiltrating water. Further research is needed on the sorption of PFAS in the presence of soil, the influence of co-contaminants, and the stability of immobilized PFAS.

\subsubsection{Solidification of PFAS-Contaminated Soil}

Sörengård et al. [86] tested the solidification of PFAS-contaminated soil with a combination of Portland cement (PC), fly ash (FA), and ground granulated blast furnace slag (GGBS) with a PC:FA:GGBS ratio of 1:1:2. This solidification was done together with chemical stabilization using several additives, such as PAC, Rembind ${ }^{\circledR}$ (AC-based and containing amorphous aluminum hydroxide and kaolin clay), pulverized zeolite, chitosan, hydrocalcite, and bentonite at a concentration of $0.2 \%(\mathrm{w} / \mathrm{w})$ of dry PFAS-contaminated soil. The results showed that most PFAS (except the PFCAs with a perfluorocarbon chain length of less than five carbon atoms, e.g., PFBA and PFPeA) were successfully stabilized with CA in the solidified soil (e.g., logK $\mathrm{K}_{d}$ increased from 1.5 $\mathrm{L} / \mathrm{kg}$ for PFOS in the soil to about $3.5 \mathrm{~L} / \mathrm{kg}$ treated with PAC) by hydrophobic sorption. Sörengård et al. recently demonstrated the long-term stabilization of PFAS in AFFF-contaminated soil, with a removal rate of up to $97 \%$ for the most important PFAS (PFOA and PFOS) [95].

The short-chains of perfluorocarbon could not be immobilized in significant amounts in stabilized/solidified soil (S/S-soil) under basic $\mathrm{pH}$ as they have a lower hydrophobic bond strength and faster diffusion in the water phase compared to the long-chains [86]. Hence, the S/S-soil, with 
large numbers of short perfluoroalkyl chains, needs $\mathrm{pH}$ adjustment to reduce leaching. Apart from the positive effects on the immobilization of PFAS, the addition of CA to soil exerts negative effects on solidification. For example, Sörengård et al. $[86,95]$ reported that unconfined compressive strength (as a measure of solidification) decreased by $38 \%$ and $14 \%$ in a carbon-poor sandy silt soil treated with $0.2 \%$ Rembind $^{\circledR}$ and PAC, respectively. This means that the solidification of soils rich in organic carbon and clay through treatment with CA may entail high costs as these soils need significantly more binder in combination with PC and the addition of sodium silicate and/or lime compared to sandy soils [86]. Further laboratory studies should be performed before S/S-treatment is implemented in the field to optimize the S/S-binder methods for the specific contaminated soil, due to the complexity of the binding of soil to aggregates.

The stability of PFAS in S/S-soil over time is not quite clear. The carbonation of FA and PC may result in a decrease in the $\mathrm{pH}$ and improvement in the electrostatic interactions between PFAS and the treated soil. Contrary to the positive effects of carbonation, the aging of CA in S/S-soil may result in low sorption capacity for PFAS or even in the desorption of PFAS [58]. Thus, more research is needed to explore the stability of PFAS in S/S-soil over time.

\subsection{Destruction of PFAS in Soil Using Thermal Treatment}

Treatment of contaminated soil by exposure to high temperatures $\left(850-1200{ }^{\circ} \mathrm{C}\right.$ ) may be an effective technique to mineralize PFAS [96]. For example, incineration in a fluidized bed incinerator at temperatures of up to $900{ }^{\circ} \mathrm{C}$ can reduce the PFOS levels to below the detection limits in the exhaust air $\left(15 \mathrm{ng} / \mathrm{m}^{3}\right)$, while also reducing solid residues $(10 \mu \mathrm{g} / \mathrm{kg}$ dry matter) and water discharges $(25 \mathrm{ng} / \mathrm{L})$ [96]. However, incineration of PFAS-contaminated soil together with other wastes may lead to the formation of highly volatile and mobile $1 \mathrm{H}$-perfluoroheptane, dioxins, furans, tetrafluoromethane, and hexafluoroethane $\left(\mathrm{C}_{2} \mathrm{~F}_{6}\right)$ [97-99]. Thus, the addition of appropriate substances, such as $\mathrm{Ca}(\mathrm{OH})_{2}$, may be required to reduce the emission of these harmful by-products [100]. More research is needed to better understand the effects of incineration on PFAS and the byproducts formed. Thermal treatment is not suitable for large masses of soil contaminated with PFAS to be subsequently landfilled due to the high costs involved [9].

\section{Treatment of Landfill Leachate Contaminated with PFAS}

In modern landfills, leachate is collected and treated on-site at local treatment plants and then discharged into a recipient water body or pumped to WWTPs [65]. Particularly in Sweden, the landfill leachate must be treated before it is delivered to WWTPs to meet the quality requirements set by the WWTP operators. Most of the traditional treatment systems for landfill leachates are not designed to remove PFAS, and thus, the extent to which they reduce the PFAS levels is not wellknown due to a lack of published data. The processes for removing PFAS from landfill leachate discussed in the literature include separation of PFAS from leachate by sorption, biological treatment, membrane-based treatments (such as nanofiltration and reverse osmosis), and compacted wetlands (Table 3). Destruction techniques used for removing PFAS from groundwater, such as electrochemical treatment, thermal treatment, wet air oxidation, and advanced oxidation processes (such as photolysis, photocatalysis, and activated persulfate oxidation), have also been discussed. 


\subsection{Separation of PFAS from Landfill Leachate}

\subsubsection{Sorption}

The sorption of PFAS to GAC (e.g., Filtrasorb 300 and 600, or AquaCarb 1240) and anion exchange (AE) materials (such as Purolite ${ }^{\circledR} \mathrm{A600}$ ) has been tested for the treatment of landfill leachate, groundwater, and drinking water $[1,58,101]$. These sorbents are more effective for eliminating long-chain PFAS than short-chain PFAS (e.g., PFOS>PFBS, in terms of removal efficiency), but they have a low sorption capacity [47, 76, 85]. As shown in Table 3, Busch et al. [1] and Yu et al. [76] found that AC can adsorb $68.2 \%$ to $99.8 \%$ of PFAS. However, in these studies, PPFAS in the treated leachates remained high (e.g., 4,079 ng/L) due to the high concentrations in raw leachate (e.g., $12,819 \mathrm{ng} / \mathrm{L}$ ) and the short residence times of the leachate through the AC filters, or high mass flows. Additionally, DOC in leachates may compete with PFAS for the adsorption sites. Short-chain PFAS, such as PFBA $\left(\mathrm{C}_{4}\right)$, PFPeA $\left(\mathrm{C}_{5}\right)$, and PFHxA $\left(\mathrm{C}_{6}\right)$, maybe inefficiently adsorbed because they are less hydrophobic compared to long-chain PFAS, such as PFNA $\left(C_{9}\right)$, PFDA $\left(C_{10}\right)$, and PFOS $\left(C_{8}\right)$, and may, therefore, be displaced by long-chain PFAS and DOC [58]. Thus, the selective nature of PFAS removal and the associated desorption of short-chain PFCAs during the co-removal of multiple PFAS must be considered during the designing and operation of the adsorption treatment processes.

\subsubsection{Membrane Technology}

Reverse osmosis (RO) and nanofiltration (NF) involve the use of semi-permeable membranes (with 1-10 $\mathrm{nm}$ and <1 $\mathrm{nm}$ pores, respectively) to remove contaminants from leachates. These are physical separation technologies that transfer PFAS from the leachate to a secondary phase (rejected water or concentrate), which then needs further treatment. Appleman et al. [101] reported that NF removed PFOS, PFOA, PFDA, PFPeA, and PFBA to below-detection limits (with >97\% removal efficiency) from artificial groundwater spiked with $1 \mu \mathrm{g} / \mathrm{L}$ of each PFAS; PFBS and PFHxS were present in extremely low concentrations (e.g., 10 and $20 \mathrm{ng} / \mathrm{L}$, respectively) in the permeate. Soriano et al. found that the NF90 membranes with a smaller pore size $(0.34 \pm 0.02 \mathrm{~nm})$ rejected over $99 \%$ of PFHxA at $100 \mathrm{mg} / \mathrm{L}$ from the industrial effluents [102]. Their results showed that size exclusion and electrostatic interaction occurred simultaneously and affected the selectivity of PFHxA separation. Reverse osmosis in WWTP was able to remove PFHXA, PFHpA, PFOA, PFNA, PFDA, PFBS, PFHXS, and PFOS below the detection levels from their initial concentrations, which varied between $3 \mu \mathrm{g} / \mathrm{L}$ for PFNA and $39 \mu \mathrm{g} / \mathrm{L}$ for PFOS [103]. After membrane-treatment, PFAS were concentrated in the rejected water, which was about $15 \%$ of the treated water volume for RO [103]. Soriano et al. showed an efficient removal of PFHxA (over 99\%) using XLE and BW30, two types of RO membranes [102]. These results indicate that both NF and RO can be effective in treating PFAS of a wide range of molecular weights. Franke et al. removed PFAS from drinking water using a combination of NF with AE or GAC adsorbents [104]. In the cited studies, water with no DOC was used, while the landfill leachates may contain significant amounts of DOC. Thus, more research is required on the membrane filtration treatments of PFAS in landfill leachate. Although RO and NF showed promising results in removing PFAS from contaminated water, Fuertes et al. [71] found a two-fold increase in the concentration of PFAS in the membrane bioreactors of the effluent treatment plants (using ultrafiltration treatment) compared to the raw leachate, indicating 
degradation of the precursor compounds, which increased the levels of some PFAS [71]. These results indicated that not all membrane methods are suitable for treating PFAS-contaminated water.

\subsubsection{Biological Treatments}

Biological treatments (BIO) applied by Busch et al. [1], Yan et al. [3], and Fuertes et al. [71] were found to be ineffective in removing PFAS from landfill leachate. Instead, the concentrations of PFCAs and PFSAs were increased with the use of these types of treatments (Table 3). This could have occurred due to the resistance of PFAS to biodegradation owing to their high-energy carbon-fluorine bonds [105], and the possible biodegradation of precursor compounds (such as N-ethyl perfluorooctane sulphonamidoethanol and fluorotelomer-based compounds, or other unidentified components) to PFCAs and PFSAs, as observed for the biological processes in WWTPs $[7,19,106]$.

Constructed wetlands (CWs) include various kinds of aerated lagoons, sedimentation tanks, reed beds, and polishing ponds. Multiple remedial processes may be conducted simultaneously in these systems, including biodegradation (aerobic and anaerobic), phytoremediation (plant uptake and enhancement of biodegradation), and sorption on diverse substances [87]. During tests in a large tropical wetland, $61 \%$ of $\sum$ PFAS and $50 \%-96 \%$ of individual PFAS were removed from landfill leachate. The most effective processes were sorption of long-chain PFAS to soils and sediments and uptake of short-chain PFAS by plants. These processes removed about $44 \%$ of $\sum$ PFAS during the passage of the leachate through a reed bed. Additionally, an aeration lagoon removed $55 \%-73 \%$ of the PFAS precursors through biotransformation, but it was ineffective in the removal of long-chain PFAS. This approach may only be suitable as a pre-treatment for landfill leachate as the concentrations of ¿PFAS in the treated leachate were still high (Table 3). However, the use of young plants or species with a high affinity for PFAS, and the substrates with high PFAS sorption capacity can potentially improve the removal of PFAS from landfill leachates in CWs.

\subsection{Techniques for the Destruction of PFAS in Landfill Leachate}

\subsubsection{Oxidation Processes}

Chemical oxidation involves the use of oxidants, such as sodium permanganate $\left(\mathrm{NaMnO}_{4}\right)$, sodium persulfate $\left(\mathrm{Na}_{2} \mathrm{~S}_{2} \mathrm{O}_{8}\right)$, hydrogen peroxide $\left(\mathrm{H}_{2} \mathrm{O}_{2}\right)$, or ozone $\left(\mathrm{O}_{3}\right)$ to degrade organic pollutants and decontaminate water. For example, $\mathrm{H}_{2} \mathrm{O}_{2}$ mixed with water generates hydroxyl radical $\left(\mathrm{OH}^{\circ}\right)$, which is an extremely strong oxidant $(E=2.33 \mathrm{~V})$ that reacts with organic molecules with the reaction rate-constants ranging between $10^{6}$ and $10^{10} \mathrm{Ms}^{-1}$ [107]. $\mathrm{H}_{2} \mathrm{O}_{2}$ is often used in conjunction with $\mathrm{Fe}^{2+}$ as a catalyst.

The efficiency with which the chemical oxidation processes degrade PFAS strongly depends on the $\mathrm{pH}$, temperature, and initial concentration of the oxidant. Ozone does not degrade PFOA and PFOS significantly at $\mathrm{pH} 4-5$ [108], but $\mathrm{NaMnO}_{4}$ has been shown to degrade $47 \%$ of PFOS in an aqueous solution at $\mathrm{pH} 4.2$ in 18 days. Increasing the $\mathrm{pH}$ to about 10-11 (by adding $\mathrm{NaOH}$ to the solution) decreases PFOS degradation to about $10 \%$ of the that achieved by treatment with $\mathrm{NaMnO}_{4}$, while the addition of $8.7 \mathrm{~g} \mathrm{O}_{3} / \mathrm{h}(2.5 \mathrm{wt} \%)$ reduces the concentrations of PFOA and PFOS from 50 $\mu \mathrm{g} / \mathrm{L}$ to about $5 \mu \mathrm{g} / \mathrm{L}$ and $7.5 \mu \mathrm{g} / \mathrm{L}$, respectively, after $4 \mathrm{~h}[108,109]$.

Ozonation is less efficient without pre-treatment; the results are best when $\mathrm{O}_{3}$ is added at an acidic $\mathrm{pH}$ and the process is continued by adding $\mathrm{O}_{3}$ at an alkaline $\mathrm{pH}$ [108]. At an acidic $\mathrm{pH}, \mathrm{O}_{3}$ 
decomposes slowly via reaction with hydroxide ions (as their concentrations are low), and dissolved $\mathrm{O}_{3}$ accumulates in the solution. When the concentration of $\mathrm{O}_{3}$ is sufficiently high in the solution (e.g., $3.5 \mathrm{mg} / \mathrm{L}$ ), making the solution alkaline, it generates large amounts of $\mathrm{OH}^{\bullet}$ that react rapidly with $\mathrm{O}_{3}$ and form abundant reactive free radicals, including potent hydroxyl radicals that can efficiently degrade PFOA and PFAS. Accumulation of $\mathrm{O}_{3}$ at an alkaline $\mathrm{pH}$ (without pre-treatment) in the solution is poor (e.g., about $0.3 \mathrm{mg} / \mathrm{L}$ at pH $=11$ ) as the large amounts of $\mathrm{OH}^{\bullet}$ continually react with $\mathrm{O}_{3}$, causing the concentrations of reactive free radicals to be low throughout the process [108]. The process can be improved by increasing the dose of the oxidant and the temperature (e.g., the kinetic rate constant of PFOS increased from $0.46 \times 10^{-2} \mathrm{~L} / \mathrm{d}$ at $25^{\circ} \mathrm{C}$ to $3.64 \times 10^{-2} \mathrm{~L} / \mathrm{d}$ at $65^{\circ} \mathrm{C}$ ) in the tests or when combined with other processes, such as photolysis [92]. A synergistic effect was observed when ozone was combined with UV or with air fractionation, whereby the removal of PFAS reached $73 \%$ and $95 \%$, respectively [108].

Heterogeneous photocatalysis is a promising solution for the removal of PFAS from contaminated water. This technique directly uses photons ( $h v$ ) from a VUV or UV to generate negatively-charged electrons $\left(\mathrm{e}^{-}\right)$and positively-charged holes $\left(\mathrm{h}^{+}\right)$, which have high oxidation capacity [110]. The positively-charged holes react with water, yielding $\mathrm{OH}^{\bullet}$ that can effectively degrade diverse organic compounds. The negatively-charged electrons migrate to the surface of the photocatalyst and react with the adsorbed water to form hydrated electrons ( $e^{-}$aq). PFAS sorbed on the catalyst's surface are attacked by these hydrated electrons and degraded into shorter-chain compounds [110].

Photocatalysis with $\mathrm{TiO}_{2}$ may degrade PFCAs (e.g., PFOA, PFNA, and PFDA), but several hours are required for satisfactory results. For example, Panchangam et al. reported that $\mathrm{TiO}_{2}$ irradiated with a $16 \mathrm{~W}$ ( $254 \mathrm{~nm}$ ) low-pressure mercury lamp could degrade $99 \%$ and mineralize $38 \%$ of PFOA and PFDA in $7 \mathrm{~h}$ [111]. The treatment time could be reduced (several-fold) by adding acid to the treated solution, for example, adding $0.225 \mathrm{M}$ perchloric acid $\left(\mathrm{HClO}_{4}\right)$ reduced the $\mathrm{pH}$ of the solution to 3 and cuts down the treatment time for PFOA from $24 \mathrm{~h}$ to $7 \mathrm{~h}$ (Ibid.). According to Panchangam et al., the presence of acid improves the ionization of PFCAs by increasing the chances of electron transfer from PFCAs to the photoholes of excited $\mathrm{TiO}_{2}$, thereby prolonging the life of the photoholes [111]. The process can be further improved by the recovery of the acid.

Furthermore, a recent development on the photocatalytic degradation of PFOA using a $\mathrm{TiO}_{2}-\mathrm{rGO}$ ( $0.1 \mathrm{~g} \mathrm{~L}^{-1}$ ) composite catalyst was shown to degrade up to $93.7 \%$ of PFOA compared to the $\mathrm{TiO}_{2}$ photocatalysis $(24 \% \pm 11 \%)$ and direct photolysis (58\% $\pm 9 \%$ ) [112]. The degradation efficiency was related to several parameters, which included the initial PFAS concentration, photocatalyst, UV lamp intensity, and media.

$\beta-\mathrm{Ga}_{2} \mathrm{O}_{3}$ is relatively more efficient as a photocatalyst than $\mathrm{TiO}_{2}$ for PFCA degradation owing to the wider band-gap of the former ( $4.8 \mathrm{eV}$ for $\mathrm{BGa}_{2} \mathrm{O}_{3}$ compared to $3.2 \mathrm{eV}$ for $\mathrm{TiO}_{2}$ ) and the higher position of its conduction band relative to the vacuum energy level (e.g., ECB values: - $2.95 \mathrm{eV}$ and - $4.21 \mathrm{eV}$, respectively) [113]. For example, Shao et al. found that PFOA was completely degraded after $65 \mathrm{~min}$ of exposure to upgraded $\beta-\mathrm{Ga}_{2} \mathrm{O}_{3}$ along with VUV irradiation at $185 \mathrm{~nm}$ and $\mathrm{pH} 4.3$ [114]. The catalytic $\beta-\mathrm{Ga}_{2} \mathrm{O}_{3}$ had a sheaf-like nanostructure consisting of plates elongated in the [1 0 ] direction, a specific surface area of $36.1 \mathrm{~m}^{2} / \mathrm{g}$, and high densities of the nanopores (2-4 $\mathrm{nm}$ and $8 \mathrm{~nm}$ ). In contrast, commercial $\beta-\mathrm{Ga}_{2} \mathrm{O}_{3}$ degraded only $38 \%$ of the PFOA in $3 \mathrm{~h}$ (which was still two times higher than the rate obtained with $\mathrm{P} 25 \mathrm{TiO}_{2}$ ) [114]. On the other hand, boron nitride (BN) was found to be quite an efficient catalyst, being 2 to 4 times more active than $\mathrm{TiO}_{2}$ [115]. Duan et al. 
[115] showed that low concentrations of PFOA were detected after 240 min of photolytic degradation using BN [115].

The removal of PFAS from landfill leachate through photocatalysis may be affected by the presence of dissolved organic matter (DOM), bicarbonate, and chlorides. The DOM and bicarbonate in leachates probably impair the photodegradation process by occupying the catalyst's surface, thereby reducing its adsorption capacity for PFAS [110]. Thus, applying photocatalysis as the final step may be an effective strategy in leachate treatment (when most of the DOM has been removed in the previous steps). Another option may be to add $\mathrm{O}_{3}$ gas to promote the removal of long-chain PFAS (e.g., PFOA), i.e., by increasing the rate at, which photo-produced $\mathrm{H}^{+}$reacts with PFOA, rather than recombining with photo-produced $\mathrm{e}^{-}[112]$. Additionally, the $\mathrm{pH}$ of the leachate should probably be adjusted to about 4 to promote high adsorption of PFAS and enhance the performance of $\mathrm{e}^{-}$and $\mathrm{H}^{+}$pairs [110]. Moreover, future research should include the evaluation of the efficiency of photocatalysis in treating short-chain PFAS in landfill leachates.

In electrochemical treatment (ET), "non-active" anodes composed of materials such as $\mathrm{Ti} / \mathrm{RuO}_{2}$, $\mathrm{SnO}_{2}, \mathrm{PbO}_{2}$, and boron-doped diamond (BDD) are used for degrading and mineralizing nonbiodegradable organic compounds, such as PFOA, PFBA, PFHxA, PFDA, PFBS, PFHxS, and PFOS [116118].

The electrochemical technique is reported to efficiently remove PFAS from wastewater and groundwater, but the required treatment time might be quite long. For example, Gomez-Ruiz et al. reported that ET treatment with a BDD electrode removed $99.7 \%$ of diverse PFAS from wastewater [119], with their total concentration dropped from 1,652 $\mu \mathrm{g} / \mathrm{L}$ to $4.2 \mu \mathrm{g} / \mathrm{L}$ during $10 \mathrm{~h}$ of treatment at a current density of $50 \mathrm{~mA} / \mathrm{cm}^{2}$ and a voltage between 13.9 and $15.3 \mathrm{~V}$. Similarly, Zhuo et al. found that a current density of $0.59 \mathrm{~mA} / \mathrm{cm}^{2}$ and an oxidation potential greater than $2.76 \mathrm{~V}$ were adequate for removing about $97.5 \%$ of PFOA from spiked water (at the concentrations of 20, 30, and $50 \mathrm{mg} / \mathrm{L}$ ) after $2 \mathrm{~h}$ of electrolysis [120]. Besides the electrochemical parameters (such as current density and voltage), the success of ET depends on the $\mathrm{pH}$ and the initial concentrations of PFAS. The degradation rate of PFOA is higher at an acidic $\mathrm{pH}$ than at an alkaline $\mathrm{pH}$. At alkaline $\mathrm{pH}, \mathrm{OH}^{-}$ migrates to the anode surface due to electrostatic attraction, which limits the sites available for degraded $\mathrm{CF}_{3}\left(\mathrm{CF}_{2}\right)_{6} \mathrm{COO}^{-}$anion [120]. The removal ratio was shown to increase with an increase in the initial PFOA concentration. Thus, ET may be an effective treatment for water with high levels of PFAS contamination at an acidic $\mathrm{pH}$.

Regarding the treatment of landfill leachate, Witt et al. recently demonstrated that $98 \%$ of PFOA was removed electrochemically under a flow through a BDD cell in a $20 \mathrm{~L}$ pilot water treatment system [121]. However, this technology is not fully developed for commercial applications, partly due to high energy demands, which increases the costs of operation. For example, $99.7 \%$ removal of PFAS from contaminated water would require approximately $256 \mathrm{kWh} / \mathrm{m}^{3}$ (corresponding to about 14 euro $/ \mathrm{m}^{3}$ ) [119]. Thus, large-scale implementation of ET would require pre-treatment of the PFAS-contaminated water (e.g., using membrane separation) and the prevention of its mixing with diluting water streams (to reduce the volumes requiring treatment).

\subsubsection{Thermal Treatment}

The thermal treatment methods for water include sonochemistry, sub-critical and supercritical water treatment, microwave-hydrothermal treatment, and wet air oxidation (WAO). 
Sonochemical treatment refers to the use of ultrasonic waves at the frequencies of $20-1000 \mathrm{kHz}$ to form cavitation bubbles in water, and hence, high vapor temperatures (near 4,000-5,000 K) in the vapor core. Thus, PFAS may be pyrolytically decomposed at bubble-water interfaces [122]. Decomposition of PFOA and PFOS results in the production of mineralized fluoride $\left(\mathrm{F}^{-}\right)$, sulfate $\left(\mathrm{SO}_{4}{ }^{2-}\right), \mathrm{CO}$, and $\mathrm{CO}_{2}$ [123]. Campbell and Hoffmann showed that the treatment's efficiency relied on the frequency of the ultrasonic radiation and the power density [124]. The measured rate constants of PFOS, PFOA, PFHxA, PFHXS, and PFBS showed that degradation increased linearly with the increase in power density (e.g., the rate constant for PFOS increased from $0.01 \mathrm{~L} / \mathrm{min}$ at 100 $\mathrm{W} / \mathrm{L}$ to $0.045 \mathrm{~L} / \mathrm{min}$ at $330 \mathrm{~W} / \mathrm{L}$ at the same frequency of $358 \mathrm{kHz}$ ). Similarly, the rate of PFAS degradation was shown to increase with an increase in the frequency (e.g., the rate constant for PFOS increased from $0.045 \mathrm{~L} / \mathrm{min}$ at $358 \mathrm{kHz}$ to $0.06 \mathrm{~L} / \mathrm{min}$ at $610 \mathrm{kHz}$ at the same power density of $330 \mathrm{~W} / \mathrm{L}$ ). Moreover, the degradation rates of PFOA and PFOS were enhanced by $12 \%$ and $23 \%$, respectively, through the application of a dual-frequency (20 and $202 \mathrm{kHz}$ ). The increase in degradation with the application of dual-frequency may be attributed to a better overlap of acoustic waves (which enhances bubble expansion and shortens collapse time), thereby strengthening the cavitation effects and the induction of sonochemical reactions [125]. The treatment cost can be reduced by combining sonification with oxidation, for example, by using persulfate $\left(\mathrm{S}_{2} \mathrm{O}_{8}{ }^{2-}\right)$ oxidant to generate sulfate radicals $\left(\mathrm{SO}_{4}{ }^{\bullet-}\right)$, which increases the efficiency of the process [126-128]. Nevertheless, the higher cost of the sonochemical treatment process compared to other destructive methods may limit its application in the treatment of PFAS [129].

According to Hori et al., pure subcritical water treatment cannot degrade PFOS, but it can degrade PFOS efficiently when used in combination with the addition of zero-valent metals (e.g., Al, $\mathrm{Cu}, \mathrm{Zn}, \mathrm{Fe}$ ) to the reaction system [125]. Zero-valent iron, $\mathrm{Fe}(0)$, provided the best synergistic results for the degradation of PFOS, followed by $\mathrm{Zn}, \mathrm{Cu}$, and $\mathrm{Al}$ (in decreasing ability of degradation), in the tests performed by the researchers. For example, adding Fe(0) powder $(>99.9 \%,<53 \mu \mathrm{m}$ at $4.8-19$ mmol concentrations) to subcritical water treatment mixtures reduced the concentrations of PFOS from 93-372 $\mu \mathrm{M}$ to $<2.2 \mu \mathrm{M}$ (at $350{ }^{\circ} \mathrm{C}, 22 \mathrm{MPa}$ after $6 \mathrm{~h}$ ), with the formation of $\mathrm{F}^{-}$ions, $46 \%-51 \%$ and no PFCA formation (Ibid.). Additionally, shorter C-F chains, such as PFHxS, could be degraded from the initial concentrations of $741 \mu \mathrm{M}$ to $97 \mu \mathrm{M}$ using subcritical water treatment combined with the addition of $19.3 \mathrm{mmol} F$ [130]. This process can be described as the adsorption of PFAS to the Fe surface and the decomposition of PFAS with rising temperature along with the release of $\mathrm{F}^{-}$ions in the solution phase above $250{ }^{\circ} \mathrm{C}$ [125]. Thus, zero-valent Fe powder with a large specific surface area should be used in subcritical water treatment to improve the decomposition of PFAS.

Supercritical water treatment is more efficient than subcritical water treatment. For example, in other tests reported by Hori et al., these treatments resulted in the decomposition of $94.8 \%$ and $84 \%$ of PFHxA, respectively, using the same concentration of Fe (9.6 mmol) [130]. However, supercritical water treatment caused an 8-fold increase in fluoroform $\left(\mathrm{CF}_{3} \mathrm{H}\right)$ creation compared to subcritical water treatment. Thus, supercritical water treatment of PFAS may be problematic from an environmental perspective as $\mathrm{CF}_{3} \mathrm{H}$ is a greenhouse gas with high diffusivity, low viscosity, and an atmospheric lifetime of approximately 270 years [131]. Moreover, both subcritical and supercritical water treatments may encounter operational problems, such as severe reactor corrosion (caused by acids formed during the treatment, such as $\mathrm{H}_{2} \mathrm{SO}_{4}$ ) or serious plugging of the reactor caused by the salts precipitating at high temperatures and low densities. This technique is not suitable for treating PFAS in landfill leachate due to operational problems and extremely high costs [132]. 
Lee et al. found that microwave (MW) irradiation at $140 \mathrm{~W}$ and $130{ }^{\circ} \mathrm{C}$ for $8 \mathrm{~h}$ degraded only $3 \%$ of PFOA (with an initial concentration of $241 \mu \mathrm{M}$ in the solution) [133]. In combination with $5 \mathrm{mM}$ $\mathrm{S}_{2} \mathrm{O}_{8}{ }^{2-}$, the method degraded $35 \%$ and $68 \%$ of PFOA at $60{ }^{\circ} \mathrm{C}$ and $90{ }^{\circ} \mathrm{C}$, respectively, after $4 \mathrm{~h}$. The process can be further improved by adding more $\mathrm{S}_{2} \mathrm{O}_{8}{ }^{2-}$. For example, in the study, the decomposition rate constant increased from 0.74 to $0.88 \mathrm{~L} / \mathrm{h}$ at $90{ }^{\circ} \mathrm{C}$ when the concentration of $\mathrm{S}_{2} \mathrm{O}_{8}{ }^{2-}$ increased from 5 to $10 \mathrm{mM}$ at acidic $\mathrm{pH}$ (e.g., 2.5) [133, 134]. The degradation rate of PFOA can be further increased by adding zero-valent iron; for example, Lee et al. recorded $58 \%$ degradation of PFOA in the presence of $3.6 \mathrm{mM} \mathrm{Fe}(0)$ and $5 \mathrm{mM} \mathrm{S}_{2} \mathrm{O}_{8}{ }^{2-}$ after $1 \mathrm{~h}$ of MW irradiation at $90{ }^{\circ} \mathrm{C}$ [133]. Aerobic and anaerobic corrosion of $\mathrm{Fe}(0)$ generate $\mathrm{Fe}^{2+}$, which accelerates the decomposition of $\mathrm{S}_{2} \mathrm{O}_{8}{ }^{2-}$ by acting as a transitional metal activator [135]. It is important to determine the optimum concentration of $\mathrm{Fe}(0)$ as surplus $\mathrm{Fe}(0)$ may release large quantities of $\mathrm{Fe}^{2+}$ ions that consume $\mathrm{SO}_{4}{ }^{\circ-}$, thereby reducing the decomposition efficiency of PFAS $[133,136]$. Moreover, chloride ions may reduce the decomposition of PFAS as they react with free sulfate radicals that limit the oxidation efficiency [134]. Thus, degradation of PFAS by using MW irradiation in combination with oxidants may be an option for treating contaminated leachate with low buffer capacity (since $\mathrm{pH}$ should be adjusted to acidic values) and low concentrations of $\mathrm{Cl}^{-}$.

Busch et al. [1] and Silva et al. [137] reported that PFAS treatment using wet air oxidation (WAO) was ineffective in removing PFAS from landfill leachate, most likely due to a short treatment time $[1,137]$ (Table 3). High concentrations of PFAS in leachates have been observed after treatment with WAO (Table 3), which can be explained by the degradation of fluorotelomer precursors to PFCAs [138].

\section{Conclusions}

The Registration, Evaluation, Authorization, and Restriction of Chemicals (REACH) should focus not only on long-chain but also on short-chain PFAS (such as PFBA and PFBS) because of their persistence, high mobility in water and soil, and difficulty in remediation and water purification. The use of PFAS in products should also be better regulated to reduce their release into the environment. Directives on the definition and classification of waste should be more specific about the concentrations of PFAS in wastes, such as contaminated soil. The Landfill Directive should include the maximal concentrations of soluble PFASs in waste that can be disposed of in landfills. The introduction of legal limits for soluble/mobile PFAS in contaminated soil would reduce the amount of PFAS in landfill leachate. Additional requirements to treat the soil before landfilling and improvements in the treatment techniques would further reduce the release of PFAS into the surrounding environment.

"Digging and dumping" continues to be the most widely used remediation technique at the sites contaminated with PFAS as the current in-situ and on-site remediation techniques are not reliable. Excavated soil may contain high amounts of PFAS and may comprise one of the major waste streams at landfills in the future. These soils have the potential to contaminate landfill leachate with PFAS, which places new demands on the leachate treatment systems at landfills. PFAS-contaminated soil, therefore, requires treatment before landfilling to reduce its potential to contaminate landfill leachate. The stabilization of PFAS-contaminated soil with AC, compost, Fe-oxides, or clay minerals may be an option to reduce the leaching of PFAS from landfilled soil. The potential to treat PFAScontaminated soil with another waste (e.g., carbon-rich waste) should be studied as this may reduce 
treatment costs, thereby enhancing sustainability. More research on the longevity of stabilized contaminants in the soil at landfills is also needed.

The installation of a cover (or encapsulation) decreases the volume of leachate in contact with the PFAS-contaminated soil in a landfill. PFAS-contaminated soil should not be disposed of in a landfill together with alkaline materials to avoid increasing the mobility of PFAS. Waste in a landfill may act as a filter for leached PFAS. Furthermore, co-contaminants, including minerals and natural organic matter, can significantly affect the remediation. Thus, the transport of PFAS through landfills should be studied in more detail.

Biological methods are not suitable for the treatment of PFAS in landfill leachate as they are inadequate in the reduction of PFAS concentrations. Membrane-based treatments, in combination with sorption on AC, might be viable for treating PFAS in landfill leachate. Advanced oxidation and thermal treatments also show promising results for degrading PFAS. Any treatment process selected should be optimized for, inter alia, leachate flow, treatment time, and concentrations of PFAS in untreated leachate, as well as, the desired levels of PFAS in the treated leachate. Foam fractionation is another technique that is not well-documented in the scientific literature. Additional research is needed to study the transformation of PFAS from contaminated water to foam, the efficiency of the process, and the treatment costs.

\section{Acknowledgments}

This work was supported by Ragn-Sells Treatment \& Detox AB and the Knowledge Foundation (KKS) within the Enforce Research Project (20160019).

\section{Author Contributions}

Igor Travar: Conceptualization, writing, and reviewing. Jean Noel Uwayezu: writing and reviewing. Jurate Kumpiene: reviewing and editing. Leo W.Y. Yeung: reviewing and editing.

\section{Competing Interests}

The authors have declared that no competing interests exist.

\section{References}

1. Busch J, Ahrens L, Sturm R, Ebinghaus R. Polyfluoroalkyl compounds in landfill leachates. Environ Pollut. 2010; 158: 1467-1471.

2. Favreau P, Poncioni-Rothlisberger C, Place BJ, Bouchex-Bellomie H, Weber A, Tremp J, et al. Multianalyte profiling of per-and polyfluoroalkyl substances (PFASs) in liquid commercial products. Chemosphere. 2017; 171: 491-501.

3. Yan H, Cousins IT, Zhang C, Zhou Q. Perfluoroalkyl acids in municipal landfill leachates from China: Occurrence, fate during leachate treatment and potential impact on groundwater. Sci Total Environ. 2015; 524: 23-31.

4. Organisation for Economic Co-operation and Development. Toward a new comprehensive global database of per-and polyfluoralkyl substances: Summary report on updating the OECD 2007 list of PFAS. Paris: Organisation for Economic Co-operation and Development; 2018; JT03431231. 
5. Ahrens L, Norström K, Viktor T, Cousins AP, Josefsson S. Stockholm Arlanda Airport as a source of per-and polyfluoroalkyl substances to water, sediment and fish. Chemosphere. 2015; 129: 33-38.

6. Baduel C, Mueller JF, Rotander A, Corfield J, Gomez-Ramos MJ. Discovery of novel per-and polyfluoroalkyl substances (PFASs) at a fire fighting training ground and preliminary investigation of their fate and mobility. Chemosphere. 2017; 185: 1030-1038.

7. Xiao F. Emerging poly-and perfluoroalkyl substances in the aquatic environment: A review of current literature. Water Res. 2017; 124: 482-495.

8. Ahrens L, Yamashita N, Yeung LW, Taniyasu S, Horii Y, Lam PK, et al. Partitioning behavior of perand polyfluoroalkyl compounds between pore water and sediment in two sediment cores from Tokyo Bay, Japan. Environ Sci Technol. 2009; 43: 6969-6975.

9. Filipovic $M$, Woldegiorgis $A$, Norström K, Bibi $M$, Lindberg $M$, Österås $A H$. Historical usage of aqueous film forming foam: A case study of the widespread distribution of perfluoroalkyl acids from a military airport to groundwater, lakes, soils and fish. Chemosphere. 2015; 129: 39-45.

10. Zhao $X$, Ding J, You $H$. Spatial distribution and temporal trends of polycyclic aromatic hydrocarbons (PAHs) in water and sediment from Songhua River, China. Environ Geochem Health. 2014; 36: 131-143.

11. Ahrens L, Yeung LW, Taniyasu S, Lam PK, Yamashita N. Partitioning of perfluorooctanoate (PFOA), perfluorooctane sulfonate (PFOS) and perfluorooctane sulfonamide (PFOSA) between water and sediment. Chemosphere. 2011; 85: 731-737.

12. Senthilkumar K, Ohi E, Sajwan K, Takasuga T, Kannan K. Perfluorinated compounds in river water, river sediment, market fish, and wildlife samples from Japan. Bull Environ Contam Toxicol. 2007; 79: 427-431.

13. Backe WJ, Day TC, Field JA. Zwitterionic, cationic, and anionic fluorinated chemicals in aqueous film forming foam formulations and groundwater from US military bases by nonaqueous largevolume injection HPLC-MS/MS. Environ Sci Technol. 2013; 47: 5226-5234.

14. Guo B, Zeng J, Brusseau ML. A mathematical model for the release, transport, and retention of per-and polyfluoroalkyl substances (PFAS) in the vadose zone. Water Resour Res. 2020; 56: e2019WR026667.

15. Brusseau ML, Anderson RH, Guo B. PFAS concentrations in soils: Background levels versus contaminated sites. Sci Total Environ. 2020; 740: 140017.

16. Hale SE, Arp HP, Slinde GA, Wade EJ, Bjørseth K, Breedveld GD, et al. Sorbent amendment as a remediation strategy to reduce PFAS mobility and leaching in a contaminated sandy soil from a Norwegian firefighting training facility. Chemosphere. 2017; 171: 9-18.

17. Houtz EF, Higgins CP, Field JA, Sedlak DL. Persistence of perfluoroalkyl acid precursors in AFFFimpacted groundwater and soil. Environ Sci Technol. 2013; 47: 8187-8195.

18. Becker AM, Gerstmann S, Frank H. Perfluorooctane surfactants in waste waters, the major source of river pollution. Chemosphere. 2008; 72: 115-121.

19. Schultz MM, Higgins CP, Huset CA, Luthy RG, Barofsky DF, Field JA. Fluorochemical mass flows in a municipal wastewater treatment facility. Environ Sci Technol. 2006; 40: 7350-7357.

20. Butt CM, Berger U, Bossi R, Tomy GT. Levels and trends of poly-and perfluorinated compounds in the arctic environment. Sci Total Environ. 2010; 408: 2936-2965.

21. Ma R, Shih K. Perfluorochemicals in wastewater treatment plants and sediments in Hong Kong. Environ Pollut. 2010; 158: 1354-1362. 
22. Dauchy X, Boiteux V, Rosin C, Munoz JF. Relationship between industrial discharges and contamination of raw water resources by perfluorinated compounds: Part II: Case study of a fluorotelomer polymer manufacturing plant. Bull Environ Contam Toxicol. 2012; 89: 531-536.

23. Boiteux V, Dauchy X, Bach C, Colin A, Hemard J, Sagres V, et al. Concentrations and patterns of perfluoroalkyl and polyfluoroalkyl substances in a river and three drinking water treatment plants near and far from a major production source. Sci Total Environ. 2017; 583: 393-400.

24. Buck RC, Franklin J, Berger U, Conder JM, Cousins IT, De Voogt P, et al. Perfluoroalkyl and polyfluoroalkyl substances in the environment: terminology, classification, and origins. Integr Environ Assess Manag. 2011; 7: 513-541.

25. Prevedouros K, Cousins IT, Buck RC, Korzeniowski SH. Sources, fate and transport of perfluorocarboxylates. Environ Sci Technol. 2006; 40: 32-44.

26. Hamid H, Li LY, Grace JR. Review of the fate and transformation of per-and polyfluoroalkyl substances (PFASs) in landfills. Environ Pollut. 2018; 235: 74-84.

27. Lang JR, Allred BM, Field JA, Levis JW, Barlaz MA. National estimate of per-and polyfluoroalkyl substance (PFAS) release to US municipal landfill leachate. Environ Sci Technol. 2017; 51: 21972205.

28 Giroud JP, Bonaparte R. Leakage through liners constructed with geomembranes-part 1. Geomembrane liners [Internet]. England: Elsevier Science Publishers; 1989 [cited 2020 November 14th]. Available from: https://trid.trb.org/view/306762.

29. Benskin JP, Li B, Ikonomou MG, Grace JR, Li LY. Per-and polyfluoroalkyl substances in landfill leachate: Patterns, time trends, and sources. Environ Sci Technol. 2012; 46: 11532-11540.

30. Official Journal of the European Union. Regulation (EC) No 850/2004 of the European Parliament and of the Council of 29 April 2004 on persistent organic pollutants and amending Directive 79/117/EEC [Internet]. Brussel: European Union; 2004 [cited 2020 November 13rd]. Available from: https://eurlex.europa.eu/LexUriServ/LexUriServ.do?uri=OJ:L:2004:229:0005:0022:EN:PDF.

31. Stockholm Convention. Annex B: Perfluorooctane sulfonic acid (PFOS), its salts and perfluorooctane sulfonyl fluoride (PFOSF), decision SC-4/17 [Internet]. Switzerland: Secretariat of the Stockholm Convention; 2009 [2020 November 13rd]. Available from: http://chm.pops.int/Implementation/IndustrialPOPs/PFOS/Overview/tabid/5221/Default.aspx.

32. European Chemical Agency. Candidate list of substances of very high concern for authorization [Internet]. Helsinki: European Chemical Agency; 2015 [cited 2020 November 13rd]. Available from: https://echa.europa.eu/sv/candidate-list-table.

33. Swedish Environmental Protection Agency. Naturvårdsverkets föreskrifter om deponering, kriterier och förfaranden för mottagning av avfall vid anläggningar för deponering av avfall. Stockholm: Swedish Environmental Protection Agency; 2004; NFS 2004:10.

34. Regulations, Guidance, and Advisories for Per-and Polyfluoroalkyl Substances. The Interstate Technology and Regulatory Council (ITRC) [Internet]. [cited 2020 November 13rd]. Available from: https://pfas-1.itrcweb.org/fact-sheets/.

35. Health Canada. Updates to health canada soil screening values for perfluoroalkylated substances (PFAS). Ottawa, Ontario: Health Canada; 2019 [cited 2019 September 7th]. Available from:

https://buyandsell.gc.ca/cds/public/2020/06/19/1e18568783a9ee9bddc91262c6d7679a/atta chment 007.pdf. 
36. Final-PFAS-Guidance-Document-dated-2019-05-28.pdf [Internet]. [cited 2019 September 9th]. Available from: https://csapsociety.bc.ca/wp-content/uploads/Final-PFAS-GuidanceDocument-dated-2019-05-28.pdf.

37. Government of Canada. Canadian Environmental Protection Act, 1999. Draft Federal Environmental Quality Guidelines for Perfluorooctane Sulfonate (PFOS) [Internet]. Ottawa: Government of Canada; 2017 [cited 2020 November 13rd]. Available from: http://www.ec.gc.ca/ese-ees/38E6993C-76AA-4486-BAEB-D3828B430A6E/PFOS En.pdf.

38. Australian Government Department of the Environment and Energy. Commonwealth Environmental management guidance on perfluorooctane sulfonic acid (PFOS) and perfluorooctanoic acid (PFOA) [Internet]. Canberra: Australian Government Department of the Environment and Energy; 2016 [2020 November 13rd]. Available from: https://www.environment.gov.au/system/files/pages/dfb876c5-581e-48b7-868c242fe69dad68/files/draft-environmental-mgt-guidance-pfos-pfoa.pdf.

39. European Union. Directive 2008/98/EC of the European parliament and of the council of 19 November 2008 on waste and repealing certain Directives. Aberdeen: Official Journal of the European Communities; 2008 [cited 2020 November 13rd]. Available from: http://eurlex.europa.eu/LexUriServ/LexUriServ.do?uri=OJ:L:2008:312:0003:0030:en:PDF.

40. European Union. Commission decision of 3 May 2000 replacing decision 94/3/EC establishing a list of wastes pursuant to article 1(a) of council directive 75/442/EEC on waste and council decision 94/904/EC establishing a list of hazardous waste pursuant to article 1(4) of council directive 91/689/EEC on hazardous waste. Aberdeen: Official Journal of the European Communities; 2000; 2000/532/EC.

41. Smith R. Regulation (EC) No 883/2004 of the European Parliament and of the Council of 29 April 2004 [Internet]. London: Macmillan Education UK; 2015 [cited 2020 December 5th]. Available from: http://link.springer.com/10.1007/978-1-137-54482-7 27.

42. Mejia-Avendaño S, Munoz G, Vo Duy S, Desrosiers M, Benoît P, Sauvé $S$, et al. Novel fluoroalkylated surfactants in soils following firefighting foam deployment during the LacMegantic railway accident. Environ Sci Technol. 2017; 51: 8313-8323.

43. Swedish Chemical Agency. Chemical analysis of selected fire-fighting foams on the Swedish market 2014. Stockholm: Swedish Chemicals Agency; 2015 [2020 November 13rd]. Available from: https://www.kemi.se/download/18.6df1d3df171c243fb23960dd/1591097411709/pm6-15.pdf.

44. McGuire ME, Schaefer C, Richards T, Backe WJ, Field JA, Houtz E, et al. Evidence of remediationinduced alteration of subsurface poly-and perfluoroalkyl substance distribution at a former firefighter training area. Environ Sci Technol. 2014; 48: 6644-6652.

45. Clarke BO, Anumol T, Barlaz M, Snyder SA. Investigating landfill leachate as a source of trace organic pollutants. Chemosphere. 2015; 127: 269-275.

46. Uwayezu JN, Yeung LW, Bäckström M. Sorption of PFOS isomers on goethite as a function of pH, dissolved organic matter (humic and fulvic acid) and sulfate. Chemosphere. 2019; 233: 896-904.

47. Du Z, Deng S, Bei Y, Huang Q, Wang B, Huang J, et al. Adsorption behavior and mechanism of perfluorinated compounds on various adsorbents-A review. J Hazard Mater. 2014; 274: 443-454.

48. Wang F, Shih K. Adsorption of perfluorooctanesulfonate (PFOS) and perfluorooctanoate (PFOA) on alumina: Influence of solution pH and cations. Water Res. 2011; 45: 2925-2930.

49. Jia C, You C, Pan G. Effect of temperature on the sorption and desorption of perfluorooctane 
sulfonate on humic acid. J Environ Sci. 2010; 22: 355-361.

50. Lang JR, Allred BM, Peaslee GF, Field JA, Barlaz MA. Release of per-and polyfluoroalkyl substances (PFASs) from carpet and clothing in model anaerobic landfill reactors. Environ Sci Technol. 2016; 50: 5024-5032.

51. Allred BM, Lang JR, Barlaz MA, Field JA. Physical and biological release of poly-and perfluoroalkyl substances (PFASs) from municipal solid waste in anaerobic model landfill reactors. Environ Sci Technol. 2015; 49: 7648-7656.

52. Fox PJ, Ross JD, Sura JM, Thiel RS. Geomembrane damage due to static and cyclic shearing over compacted gravelly sand. Geosynth Int. 2011; 18: 272-279.

53. Khalil MJ, Gupta R, Sharma K. Microbiological degradation of municipal solid waste in landfills for LFG generation [Internet]. Rohtak: Enhanced Research Publications; 2014. Available from: https://www.erpublication.org/published paper/IJETR APRIL 2014 STET 03.pdf.

54. Mahinroosta R, Senevirathna L. A review of the emerging treatment technologies for PFAS contaminated soils. J Environ Manage. 2020; 255: 109896.

55. Duchesne AL, Brown JK, Patch DJ, Major D, Weber KP, Gerhard JI. Remediation of PFAScontaminated soil and granular activated carbon by smoldering combustion. Environ Sci Technol. 2020; 54: 12631-12640.

56. Liu Y, Qi F, Fang C, Naidu R, Duan L, Dharmarajan R, Annamalai P. The effects of soil properties and co-contaminants on sorption of perfluorooctane sulfonate (PFOS) in contrasting soils. Environ Technol Innov. 2020; 19: 100965.

57. Zhang K, Huang J, Yu G, Zhang Q, Deng S, Wang B. Destruction of perfluorooctane sulfonate (PFOS) and perfluorooctanoic acid (PFOA) by ball milling. Environ Sci Technol. 2013; 47: 64716477.

58. McCleaf P, Englund S, Östlund A, Lindegren K, Wiberg K, Ahrens L. Removal efficiency of multiple poly-and perfluoroalkyl substances (PFASs) in drinking water using granular activated carbon (GAC) and anion exchange (AE) column tests. Water Res. 2017; 120: 77-87.

59. Kim M, Li LY, Grace JR, Benskin JP, Ikonomou MG. Compositional effects on leaching of stainguarded (perfluoroalkyl and polyfluoroalkyl substance-treated) carpet in landfill leachate. Environ Sci Technol. 2015; 49: 6564-6573.

60. Higgins CP, Luthy RG. Sorption of perfluorinated surfactants on sediments. Environ Sci Technol. 2006; 40: 7251-7256.

61. United States Environmental Protection Agency. Advancing sustainable materials management: Facts and figures report [Internet]. Washington, DC: United States Environmental Protection Agency; 2015 [cited 2020 November 13rd]. Available from: https://www.epa.gov/facts-andfigures-about-materials-waste-and-recycling/advancing-sustainable-materials-management.

62. European Environment Agency. Diversion of waste from landfill [Internet]. Copenhagen: European Environment Agency; 2019 [cited 2020 November 13rd]. Available from: https://www.eea.europa.eu/data-and-maps/indicators/diversion-from-landfill/assessment.

63. Environment Protection Authority. Landfill disposal criteria for PFAS-contaminated waste [Internet]. Adelaide: Environment Protection Authority; 2019 [cited 2020 November 13rd]. Available from: https://www.epa.sa.gov.au/files/14469 guide pfas landfill disposal.pdf.

64. Woldegiorgis A, Andersson J, Remberger M, Kaj L, Ekheden Y, Blom L, et al. Results from the Swedish national screening programme 2005: Subreport 3: Perflourinated alkylated substances (PFAS). Stockholm: IVL Svenska Miljöinstitutet AB; 2006 [cited 2020 November 14th]. Available 
from: http://miljobarometern.stockholm.se/content/docs/tema/kemikalier/IVLB1698.pdf.

65. Masoner JR, Kolpin DW, Cozzarelli IM, Smalling KL, Bolyard SC, Field JA, et al. Landfill leachate contributes per-/poly-fluoroalkyl substances (PFAS) and pharmaceuticals to municipal wastewater. Environ Sci Water Res Technol. 2020; 6: 1300-1311.

66. Huset CA, Barlaz MA, Barofsky DF, Field JA. Quantitative determination of fluorochemicals in municipal landfill leachates. Chemosphere. 2011; 82: 1380-1386.

67. Gewurtz SB, Backus SM, De Silva AO, Ahrens L, Armellin A, Evans M, et al. Perfluoroalkyl acids in the Canadian environment: Multi-media assessment of current status and trends. Environ Int. 2013; 59: 183-200.

68. Kallenborn R, Berger U, Järnberg U, Dam M, Hedlund B, Lundgren A, et al. Perfluorinated alkylated substances (PFAS) in the nordic environment. Copenhagen: Nordic Council of Ministers; 2004.

69. Eggen T, Moeder M, Arukwe A. Municipal landfill leachates: A significant source for new and emerging pollutants. Sci Total Environ. 2010; 408: 5147-5157.

70. Perkola N, Sainio P. Survey of perfluorinated alkyl acids in Finnish effluents, storm water, landfill leachate and sludge. Environ Sci Pollut Res. 2013; 20: 7979-7987.

71. Fuertes I, Gómez-Lavín S, Elizalde MP, Urtiaga A. Perfluorinated alkyl substances (PFASs) in northern Spain municipal solid waste landfill leachates. Chemosphere. 2017; 168: 399-407.

72. Modin H, Roslund A, Hallgren P, Törneman N, Arvidsson I, Liden A, et al. PFAS på Avfallsanläggningar. Malmö: Avfall Sverige; 2018; Avfall Sverige Rapport 2018: 25.

73. Zhang R, Yan W, Jing C. Mechanistic study of PFOS adsorption on kaolinite and montmorillonite. Colloids and surfaces A: Physicochemical and engineering aspects. 2014; 462: 252-258.

74. Gallen C, Drage D, Kaserzon S, Baduel C, Gallen M, Banks A, et al. Occurrence and distribution of brominated flame retardants and perfluoroalkyl substances in Australian landfill leachate and biosolids. J Hazard Mater. 2016; 312: 55-64.

75. Li B, Li LY, Grace JR. Adsorption and hydraulic conductivity of landfill-leachate perfluorinated compounds in bentonite barrier mixtures. J Environ Manage. 2015; 156: 236-243.

76. Yu Q, Zhang R, Deng S, Huang J, Yu G. Sorption of perfluorooctane sulfonate and perfluorooctanoate on activated carbons and resin: Kinetic and isotherm study. Water Res. 2009; 43: 1150-1158.

77. Mejia-Avendaño S, Zhi Y, Yan B, Liu J. Sorption of polyfluoroalkyl surfactants on surface soils: Effect of molecular structures, soil properties, and solution chemistry. Environ Sci Technol. 2020; 54: 1513-1521.

78. Wang F, Liu C, Shih K. Adsorption behavior of perfluorooctanesulfonate (PFOS) and perfluorooctanoate (PFOA) on boehmite. Chemosphere. 2012; 89: 1009-1014.

79. Schumacher M, Christl I, Vogt RD, Barmettler K, Jacobsen C, Kretzschmar R. Chemical composition of aquatic dissolved organic matter in five boreal forest catchments sampled in spring and fall seasons. Biogeochemistry. 2006; 80: 263-275.

80. Das P, Kambala V, Mallavarapu M, Naidu R. Remediation of perfluorooctane sulfonate in contaminated soils by modified clay adsorbent-a risk-based approach. Water Air Soil Pollut. 2013; 224: 1714.

81. Zhao L, Bian J, Zhang Y, Zhu L, Liu Z. Comparison of the sorption behaviors and mechanisms of perfluorosulfonates and perfluorocarboxylic acids on three kinds of clay minerals. Chemosphere. 2014; 114: 51-58. 
82. Chen H, Chen S, Quan X, Zhao Y, Zhao H. Sorption of perfluorooctane sulfonate (PFOS) on oil and oil-derived black carbon: Influence of solution $\mathrm{pH}$ and [Ca ${ }^{2+}$. Chemosphere. 2009; 77: 14061411.

83. Askeland M, Clarke BO, Cheema SA, Mendez A, Gasco G, Paz-Ferreiro J. Biochar sorption of PFOS, PFOA, PFHxS and PFHxA in two soils with contrasting texture. Chemosphere. 2020; 249: 126072.

84. Kupryianchyk D, Hale SE, Breedveld GD, Cornelissen G. Treatment of sites contaminated with perfluorinated compounds using biochar amendment. Chemosphere. 2016; 142: 35-40.

85. Ochoa-Herrera V, Sierra-Alvarez R. Removal of perfluorinated surfactants by sorption onto granular activated carbon, zeolite and sludge. Chemosphere. 2008; 72: 1588-1593.

86. Sörengård M, Kleja DB, Ahrens L. Stabilization and solidification remediation of soil contaminated with poly-and perfluoroalkyl substances (PFASs). J Hazard Mater. 2019; 367: 639646.

87. Yin T, Chen H, Reinhard M, Yi X, He Y, Gin KY. Perfluoroalkyl and polyfluoroalkyl substances removal in a full-scale tropical constructed wetland system treating landfill leachate. Water Res. 2017; 125: 418-426.

88. Kucharzyk KH, Darlington R, Benotti M, Deeb R, Hawley E. Novel treatment technologies for PFAS compounds: A critical review. J Environ Manage. 2017; 204: 757-764.

89. Milinovic J, Lacorte S, Vidal M, Rigol A. Sorption behaviour of perfluoroalkyl substances in soils. Sci Total Environ. 2015; 511: 63-71.

90. Chen YC, Lo SL, Li NH, Lee YC, Kuo J. Sorption of perfluoroalkyl substances (PFASs) onto wetland soils. Desalination Water Treat. 2013; 51: 7469-7475.

91. Qian J, Shen M, Wang P, Wang C, Hou J, Ao Y, et al. Adsorption of perfluorooctane sulfonate on soils: effects of soil characteristics and phosphate competition. Chemosphere. 2017; 168: 13831388.

92. Werner D, Higgins CP, Luthy RG. The sequestration of PCBs in Lake Hartwell sediment with activated carbon. Water Res. 2005; 39: 2105-2113.

93. Johnson RL, Anschutz AJ, Smolen JM, Simcik MF, Penn RL. The adsorption of perfluorooctane sulfonate onto sand, clay, and iron oxide surfaces. J Chem Eng Data. 2007; 52: 1165-1170.

94. ChunHui Z, Yi P, XiaMeng N, Ke N. Determination of perfluoroalkyl substances in municipal landfill leachates from Beijing, China. Asian J Chem. 2014; 26: 3833-3836.

95. Sörengård M, Gago-Ferrero P, Kleja DB, Ahrens L. Laboratory-scale and pilot-scale stabilization and solidification $(\mathrm{S} / \mathrm{S})$ remediation of soil contaminated with per-and polyfluoroalkyl substances (PFASs). J Hazard Mater. 2021; 402: 123453.

96. Danish Environmental Protection Agency. Survey of PFOS, PFOA and other perfluoroalkyl and polyfluoroalkylsub-stances. Copenhagen K, Denmark: The Danish Environmental Protection Agency; 2013; Environmental Project No. 1475.

97. Krusic PJ, Marchione AA, Roe DC. Gas-phase NMR studies of the thermolysis of perfluorooctanoic acid. J Fluor Chem. 2005; 126: 1510-1516.

98. McKay G. Dioxin characterisation, formation and minimisation during municipal solid waste (MSW) incineration. Chem Eng J. 2002; 86: 343-368.

99. Yamada T, Taylor PH, Buck RC, Kaiser MA, Giraud RJ. Thermal degradation of fluorotelomer treated articles and related materials. Chemosphere. 2005; 61: 974-984.

100.Wang F, Shih K, Lu X, Liu C. Mineralization behavior of fluorine in perfluorooctanesulfonate (PFOS) during thermal treatment of lime-conditioned sludge. Environ Sci Technol. 2013; 47: 


\section{1-2627.}

101.Appleman TD, Dickenson ER, Bellona C, Higgins CP. Nanofiltration and granular activated carbon treatment of perfluoroalkyl acids. J Hazard Mater. 2013; 260: 740-746.

102.Soriano A, Gorri D, Urtiaga A. Selection of high flux membrane for the effective removal of shortchain perfluorocarboxylic acids. Ind Eng Chem Res. 2019; 58: 3329-3338.

103.Thompson J, Eaglesham G, Reungoat J, Poussade $Y$, Bartkow M, Lawrence $M$, et al. Removal of PFOS, PFOA and other perfluoroalkyl acids at water reclamation plants in South East Queensland Australia. Chemosphere. 2011; 82: 9-17.

104.Franke V, McCleaf P, Lindegren K, Ahrens L. Efficient removal of per-and polyfluoroalkyl substances (PFASs) in drinking water treatment: Nanofiltration combined with active carbon or anion exchange. Environ Sci Water Res Technol. 2019; 5: 1836-1843.

105.Kwon BG, Lim HJ, Na SH, Choi BI, Shin DS, Chung SY. Biodegradation of perfluorooctanesulfonate (PFOS) as an emerging contaminant. Chemosphere. 2014; 109: 221-225.

106.Sinclair E, Kannan K. Mass loading and fate of perfluoroalkyl surfactants in wastewater treatment plants. Environ Sci Technol. 2006; 40: 1408-1414.

107.Trojanowicz M, Bojanowska-Czajka A, Bartosiewicz I, Kulisa K. Advanced oxidation/reduction processes treatment for aqueous perfluorooctanoate (PFOA) and perfluorooctanesulfonate (PFOS)-a review of recent advances. Chem Eng J. 2018; 336: 170-199.

108.Lin AY, Panchangam SC, Chang CY, Hong PA, Hsueh HF. Removal of perfluorooctanoic acid and perfluorooctane sulfonate via ozonation under alkaline condition. J Hazard Mater. 2012; 243: 272-277.

109.Liu CS, Shih K, Wang F. Oxidative decomposition of perfluorooctanesulfonate in water by permanganate. Sep Purif Technol. 2012; 87: 95-100.

110.Xu B, Ahmed MB, Zhou JL, Altaee A, Wu M, Xu G. Photocatalytic removal of perfluoroalkyl substances from water and wastewater: Mechanism, kinetics and controlling factors. Chemosphere. 2017; 189: 717-729.

111.Panchangam SC, Lin AY, Shaik KL, Lin CF. Decomposition of perfluorocarboxylic acids (PFCAs) by heterogeneous photocatalysis in acidic aqueous medium. Chemosphere. 2009; 77: 242-248.

112.Gomez-Ruiz B, Ribao P, Diban N, Rivero MJ, Ortiz I, Urtiaga A. Photocatalytic degradation and mineralization of perfluorooctanoic acid (PFOA) using a composite $\mathrm{TiO}_{2}-\mathrm{rGO}$ catalyst. J Hazard Mater. 2018; 344: 950-957.

113.Zhao B, Zhang P. Photocatalytic decomposition of perfluorooctanoic acid with $\beta-\mathrm{Ga}_{2} \mathrm{O}_{3}$ wide bandgap photocatalyst. Catal Commun. 2009; 10: 1184-1187.

114 Shao T, Zhang P, Jin L, Li Z. Photocatalytic decomposition of perfluorooctanoic acid in pure water and sewage water by nanostructured gallium oxide. Appl Catal B. 2013; 142: 654-661.

115.Duan L, Wang B, Heck K, Guo S, Clark CA, Arredondo J, et al. Efficient photocatalytic PFOA degradation over boron nitride. Environ Sci Technol Lett. 2020; 7: 613-619.

116.Schaefer CE, Choyke S, Ferguson PL, Andaya C, Burant A, Maizel A, et al. Electrochemical transformations of perfluoroalkyl acid (PFAA) precursors and PFAAs in groundwater impacted with aqueous film forming foams. Environ Sci Technol. 2018; 52: 10689-10697.

117.Carter KE, Farrell J. Oxidative destruction of perfluorooctane sulfonate using boron-doped diamond film electrodes. Environ Sci Technol. 2008; 42: 6111-6115.

118.Urtiaga A, Fernández-González C, Gómez-Lavín S, Ortiz I. Kinetics of the electrochemical mineralization of perfluorooctanoic acid on ultrananocrystalline boron doped conductive 
diamond electrodes. Chemosphere. 2015; 129: 20-26.

119.Gomez-Ruiz B, Gómez-Lavín S, Diban N, Boiteux V, Colin A, Dauchy X, et al. Efficient electrochemical degradation of poly-and perfluoroalkyl substances (PFASs) from the effluents of an industrial wastewater treatment plant. Chem Eng J. 2017; 322: 196-204.

120.Zhuo Q, Deng S, Yang B, Huang J, Wang B, Zhang T, et al. Degradation of perfluorinated compounds on a boron-doped diamond electrode. Electrochim Acta. 2012; 77: 17-22.

121. Witt S, Rancis N, Ensch M, Maldonado V. Electrochemical destruction of 'forever chemicals': The right solution at the right time. Electrochem Soc Interface. 2020; 29: 73.

122. Moriwaki H, Takagi Y, Tanaka M, Tsuruho K, Okitsu K, Maeda Y. Sonochemical decomposition of perfluorooctane sulfonate and perfluorooctanoic acid. Environ Sci Technol. 2005; 39: 3388-3392.

123. Vecitis CD, Park H, Cheng J, Mader BT, Hoffmann MR. Kinetics and mechanism of the sonolytic conversion of the aqueous perfluorinated surfactants, perfluorooctanoate (PFOA), and perfluorooctane sulfonate (PFOS) into inorganic products. J Phys Chem A. 2008; 112: 4261-4270.

124.Campbell T, Hoffmann MR. Sonochemical degradation of perfluorinated surfactants: Power and multiple frequency effects. Sep Purif Technol. 2015; 156: 1019-1027.

125. Hori H, Nagaoka Y, Yamamoto A, Sano T, Yamashita N, Taniyasu S, et al. Efficient decomposition of environmentally persistent perfluorooctanesulfonate and related fluorochemicals using zerovalent iron in subcritical water. Environ Sci Technol. 2006; 40: 1049-1054.

126.Lei YJ, Tian Y, Sobhani Z, Naidu R, Fang C. Synergistic degradation of PFAS in water and soil by dual-frequency ultrasonic activated persulfate. Chem Eng J. 2020; 388: 124215.

127. Hao F, Guo W, Wang A, Leng Y, Li H. Intensification of sonochemical degradation of ammonium perfluorooctanoate by persulfate oxidant. Ultrason Sonochem. 2014; 21: 554-558.

128. Hori H, Yamamoto A, Hayakawa E, Taniyasu S, Yamashita N, Kutsuna S, et al. Efficient decomposition of environmentally persistent perfluorocarboxylic acids by use of persulfate as a photochemical oxidant. Environ Sci Technol. 2005; 39: 2383-2388.

129. Nzeribe BN, Crimi M, Thagard SM, Holsen TM. Physico-chemical processes for the treatment of per-and polyfluoroalkyl substances (PFAS): A review. Crit Rev Environ Sci Technol. 2019; 49: 866915.

130. Hori H, Nagaoka Y, Sano T, Kutsuna S. Iron-induced decomposition of perfluorohexanesulfonate in sub-and supercritical water. Chemosphere. 2008; 70: 800-806.

131. Forster $P$, Ramaswamy V, Artaxo P, Berntsen T, Betts R, Fahey DW, et al. Changes in atmospheric constituents and in radiative forcing. Chapter 2. In Climate Change 2007. Cambridge: Cambridge University; 2007.

132. Kritzer P, Dinjus E. An assessment of supercritical water oxidation (SCWO): Existing problems, possible solutions and new reactor concepts. Chem Eng J. 2001; 83: 207-214.

133.Lee YC, Lo SL, Chiueh PT, Liou YH, Chen ML. Microwave-hydrothermal decomposition of perfluorooctanoic acid in water by iron-activated persulfate oxidation. Water Res. 2010; 44: 886-892.

134.Lee Y, Lo S, Kuo J, Hsieh C. Decomposition of perfluorooctanoic acid by microwaveactivated persulfate: Effects of temperature, pH, and chloride ions. Front Environ Sci Eng. 2012; 6: 17-25.

135. House DA. Kinetics and mechanism of oxidations by peroxydisulfate. Chem Rev. 1962; 62: 185203.

136.Liang C, Bruell CJ, Marley MC, Sperry KL. Persulfate oxidation for in situ remediation of TCE. I. Activated by ferrous ion with and without a persulfate-thiosulfate redox couple. Chemosphere. 
2004; 55: 1213-1223.

137.Silva AC, Dezotti M, Sant'Anna Jr GL. Treatment and detoxification of a sanitary landfill leachate. Chemosphere. 2004; 55: 207-214.

138. Rhoads KR, Janssen EM, Luthy RG, Criddle CS. Aerobic biotransformation and fate of N-ethyl perfluorooctane sulfonamidoethanol (N-EtFOSE) in activated sludge. Environ Sci Technol. 2008; 42: 2873-2878.

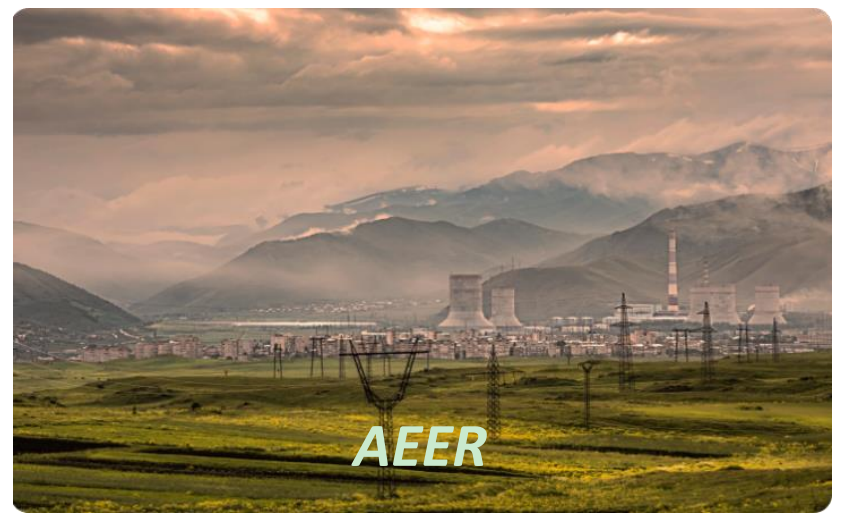

Enjoy $A E E R$ by:

1. Submitting a manuscript

2. Joining in volunteer reviewer bank

3. Joining Editorial Board

4. Guest editing a special issue

For more details, please visit:

http://www.lidsen.com/journals/aeer 